\title{
Ozone treatment of ballast water on the oil tanker S/T Tonsina: chemistry, biology and toxicity
}

\author{
Russell P. Herwig ${ }^{1, *}$, Jeffery R. Cordell ${ }^{1}$, Jake C. Perrins ${ }^{1}$, Paul A. Dinnel ${ }^{2}$, \\ Robert W. Gensemer ${ }^{3,7}$, William A. Stubblefield ${ }^{3,7}$, Gregory M. Ruiz ${ }^{4}$, \\ Joel A. Kopp ${ }^{5,8}$, Marcia L. House ${ }^{1,9}$, William J. Cooper ${ }^{6}$
}

\author{
${ }^{1}$ School of Aquatic and Fishery Sciences, Box 355020, University of Washington, Seattle, Washington 98195-5020, USA \\ ${ }^{2}$ Shannon Point Marine Center, Western Washington University, 1900 Shannon Point Road, Anacortes, Washington 98221, USA \\ ${ }^{3}$ ENSR International, 4303 West LaPorte Avenue, Fort Collins, Colorado 80521, USA \\ ${ }^{4}$ Smithsonian Environmental Research Center, 647 Contees Wharf Road, PO Box 28, Edgewater, Maryland 21307-0028, USA \\ ${ }^{5}$ Petrotechnical Resources Alaska, 310 K Street, Suite 407, Anchorage, Alaska 99510, USA \\ ${ }^{6}$ Department of Chemistry and Center for Marine Science, University of North Carolina at Wilmington, \\ 5600 Marvin K. Moss Lane, Wilmington, North Carolina 28409, USA \\ Present addresses: \\ ${ }^{7}$ Parametrix Inc., 33972 Texas Street Southwest, Albany, Oregon 97321, USA \\ ${ }^{8}$ Consulate General Monterrey, US State Department, PO Box 9002, Brownsville, Texas 78520, USA \\ ${ }^{9}$ Northwest Indian Fisheries Commission, 6730 Martin Way East, Olympia, Washington 98516, USA
}

\begin{abstract}
Worldwide transfer and introduction of non-indigenous species in ballast water causes significant environmental and economic impact. One way to address this problem is to remove or inactivate organisms that are found in ballast water. In this study, 3 experiments were conducted in Puget Sound, Washington, USA, using a prototype ozone treatment system installed on a commercial oil tanker, the $S / T$ Tonsina. Treatment consisted of ozone gas diffused into a ballast tank for 5 and $10 \mathrm{~h}$. Treatment and control tanks were sampled during the ozonation period for chemistry, culturable bacteria, phytoplankton and zooplankton. Selected fish and invertebrates were placed in cages deployed in the treatment and control tanks. Ozone introduced into seawater rapidly converts bromide $\left(\mathrm{Br}^{-}\right)$to bromines $\left(\mathrm{HOBr} / \mathrm{OBr}^{-}\right)$, compounds that are disinfectants. These were measured as total residual oxidant (TRO). Ozone treatment inactivated large portions of culturable bacteria, phytoplankton and zooplankton. The highest reductions observed were $99.99 \%$ for the culturable bacteria, $>99 \%$ for dinoflagellates and $96 \%$ for zooplankton. Caged animal results varied among taxa and locations in the ballast tank. Sheepshead minnows and mysid shrimp were most susceptible, shore crabs and amphipods the least. Distribution of ozone in the treatment tank was not homogenous during experiments, as suggested by the observed TRO concentrations and lower efficacies for inactivating the different taxa in selected ballast tank locations. Low concentrations of bromoform, a disinfection byproduct, were found in treated ballast water.
\end{abstract}

KEY WORDS: Aquatic nuisance species · Non-indigenous species · Ballast water - Ozone treatment · Bromine $\cdot$ Total residual oxidant

\section{INTRODUCTION}

Worldwide transfer and introduction of non-indigenous species (NIS) by human activities has significant ecological, economic and human-health impacts (Wilcove et al. 1998, Pimentel et al. 2000). Most attention has focused on invasions in terrestrial and freshwater habitats, but NIS invasions have also become a potent force changing coastal marine ecosystems. At least 400 marine and estuarine NIS are established in North America and over 200 of these species can occur in one estuary (Cohen et al. 1995, Ruiz et al. 1997, 2000). Some 
of these species have become numerically or functionally dominant, and have significant impacts on population, community and ecosystem-level processes (Cloern 1996, Ruiz et al. 1999, Grosholz et al. 2000).

The National Invasive Species Act of 1996 (NISA) created a program whereby vessels arriving from outside of the Exclusive Economic Zone (EEZ) voluntarily conduct open-ocean ballast water exchange (BWE), or use an approved alternate treatment of ballast water permitting ballast tanks to be discharged in US ports. Recently, individual states (e.g. California, Maryland, Oregon, Washington and Virginia) passed and implemented similar laws, some making BWE mandatory. BWE can usually be implemented and does not require retrofitting or installing new technology, but it is often viewed as a 'stop-gap' measure. BWE has some significant limitations, including ship safety issues, costs of compliance and variable effectiveness (Woodward et al. 1992, National Research Council 1996, Waite 2002, Matheickal \& Raaymakers 2004). Following rule making in 2004, ballast water management is now mandatory for all areas of the United States (Code of Federal Regulations, Title 33, Part 151, Subparts C and D). Individual states (e.g. California, Maryland, Oregon, Washington and Virginia) passed and implemented similar laws, sometimes making BWE mandatory even for coastal traffic that would not arrive from beyond the EEZ. The United States does not require vessels to deviate from its voyage or delay its voyage to conduct a BWE. Individual US states may impose diversion and delay by requiring ships to perform BWE 50 nautical miles from shore.

A number of ballast treatment methods are being explored as alternatives to BWE, but their evaluation is at an early stage (National Research Council 1996, Hallegraeff 1998). Presently, the US Coast Guard (directed by NISA) requires alternative treatments to be at least as effective as BWE. More recently, the International Maritime Organization (IMO) (2004) adopted treatment standards and the state of Washington also established interim treatment standards (Washington Department of Fish and Wildlife 2002).

Ozone has been used as a disinfectant since the late 1800 s, is used widely in Europe and, to a lesser extent, in the U.S in drinking water treatment (Hoigné 1998). It is biocidal oxidant that is unstable in water (Langlais et al. 1991). Ozone chemistry in seawater differs from that in freshwater because of the presence of bromide ion (Oemcke \& van Leeuwen 1998). Bromide ion catalytically decomposes ozone (Fig. 1) (von Gunten et al. 1996, von Gunten \& Oliveras 1998, Salhi \& von Gunten 1999, von Gunten \& Pinkernell 2000, Pinkernell \& von Gunten 2001, Gallard et al. 2003, Gujer \& von Gunten 2003, von Gunten 2003a, b). In seawater, the primary brominated compounds formed by ozone are hypobro-

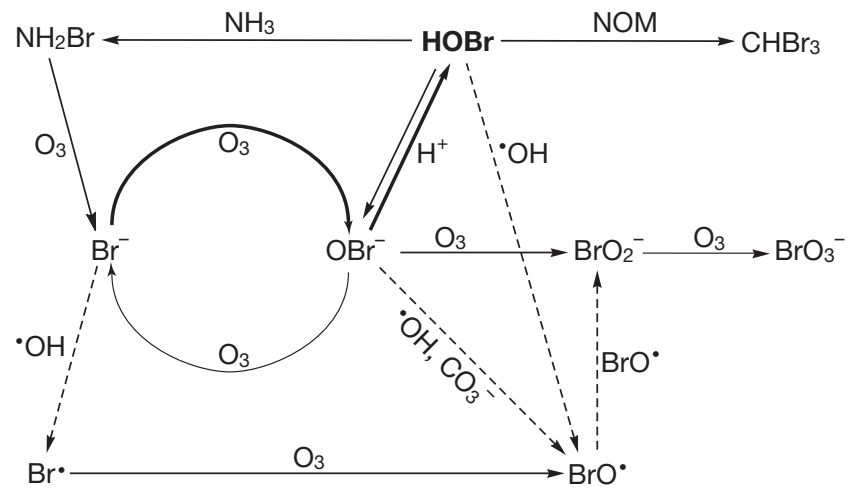

Fig. 1. Reaction pathways for decomposition of ozone in seawater showing formation of hypobromite $\left(\mathrm{OBr}^{-}\right)$, hypobromous acid $(\mathrm{HOBr})$, and disinfection byproducts bromate ion $\left(\mathrm{BrO}_{3}^{-}\right)$and bromoform $\left(\mathrm{CHBr}_{3}\right)$. NOM = natural organic matter. (Adapted from Driedger et al. [2001] with permission from Elsevier). Thick lines: preferred steps in seawater suggested by shipboard experiments performed onboard $S / T$ Tonsina; thin lines: pathways found in bromide-containing water; dotted lines: reaction steps involving free radicals

mous acid $(\mathrm{HOBr})$, which is in equilibrium with hypobromite $\left(\mathrm{OBr}^{-}\right)$. These compounds have disinfection properties. Bromoform, a disinfection byproduct, is formed by a reaction with natural organic matter in the water.

The chemistry of ozone in seawater is complex (Fig. 1). In the presence of ammonia, $\mathrm{HOBr} / \mathrm{OBr}^{-}$will react rapidly to form monobromamine (Johnson \& Overby 1971, Haag \& Hoigné 1984, Yang et al. 1999, Lei et al. 2004, Perrins et al. in press). Monobromamine can disproportionate to $\mathrm{NHBr}_{2}$ and $\mathrm{NH}_{3}$ (e.g. Lei et al. 2004) or with excess $\mathrm{HOBr} / \mathrm{OBr}^{-}$it can react further to form $\mathrm{N}_{2}$ and bromide (e.g. Brunetto et al. 1989, Hofman \& Andrews 2001). Monobromamine is unstable and will decompose to ammonia and bromide ion (Hofman \& Andrews 2001).

In this study, we examined the chemistry, biology and toxicity of a prototype treatment system that diffused ozone into a ship's ballast tank containing seawater. We conducted 3 experiments on a commercial oil tanker during September and November 2001 in Puget Sound, Washington, USA.

\section{MATERIALS AND METHODS}

S/T Tonsina, and prototype ozone system. The $S / T$ Tonsina (since sold and re-named) was a $265 \mathrm{~m}$ (869ft) American-flagged oil tanker operated by Alaska Tanker Company (Portland, Oregon) transporting crude oil mainly between Valdez, Alaska, and refineries on the west coast of the United States. The ship had a capacity of $4.16 \times 10^{7} 1$ or $4.16 \times 10^{4} \mathrm{~m}^{3}$ in 12 ballast 
tanks, and 807000 barrels $\left(1.28 \times 10^{5} \mathrm{~m}^{3}\right)$ of crude oil in 12 cargo tanks. The ship was double-hulled, with space between the hulls divided transversely for carrying ballast water when the ship was empty or partially loaded. These ballast tanks were along the outer hull and double bottom area.

In fall 2000, a prototype Nutech-O3 (McLean, Virginia) ozonation system was installed on the $S / T$ Tonsina. This prototype, known as the SCX 2000, fit in a standard ISO 20 foot $(6.1 \mathrm{~m})$ container, which was installed on the stack deck, an exterior location on the ship's stern. Ozone was produced by injecting oxygenenriched compressed air through a series of watercooled electrodes. In each electrode, a high voltage corona discharge (electric arc) was created, using a standard ship's $480 \mathrm{~V}$ power transformed to more than $10000 \mathrm{~V}$. A fraction of the oxygen-rich air passing through each corona gap was converted into ozone, which was collected and piped into one of the ballast tanks, through a system of flow meters and stainless steel pipe. Ozone was distributed into the tank through custom designed ceramic coated stone diffusers, arranged to maximize the distribution and contact time of the ozone in the ballast water.

Ballast tank sampling. The No. 3 port (3P) and number 3 starboard (3S) ballast tanks were used for ozonation and controls, respectively (Fig. 2). The 3P tank was divided into A (fore) and B (aft) sections, and the $3 \mathrm{~S}$ tank into $\mathrm{C}$ (fore) and D (aft) sections for duplicate sampling. Sections $\mathrm{A}, \mathrm{B}, \mathrm{C}$, and $\mathrm{D}$ were sampled in Expt 1 and Sections $A, B$, and $C$ were sampled in Expts 2 and 3. For all samples except zooplankton and caged animals (see later subsection), water from each tank section (A B, C, or D) was sampled at 3,9 and $15 \mathrm{~m}$ below the ship's deck using a 5 l Niskin water sampler (General Oceanics). Both the experimental and control ballast tank sections were sampled before ozonation began $(0 \mathrm{~h})$ and at 2.5 and $5.0 \mathrm{~h}$ during ozonation for Expt 1, and at 2.5, 5.0, 7.5, and $10.0 \mathrm{~h}$ during ozonation for Expts 2 and 3.

Chemistry. General water chemistry: Subsamples from the Niskin water samplers were placed in clean Nalgene containers, and analyzed (following the instructions) with the Hach DREL/2010 Water Quality Laboratory kit (Hach Company). pH was determined using a Hach Portable $\mathrm{pH}$ Meter. Dissolved oxygen (DO) was measured with a Model 21800-022
Traceable $^{\circledR}$ DO meter that was air calibrated and adjusted to compensate for salinity. Salinity was measured using a conductivity meter with a range of 0 to 80 PSU (Hach Company). Temperature was determined using a field thermometer. Samples for inorganic nutrients (orthophosphate, nitrite, nitrate, ammonia, silicic acid) and dissolved organic carbon (DOC) were frozen on board ship and stored frozen until analyzed. Inorganic nutrients and dissolved DOC were analyzed at the Marine Chemistry Laboratory in the School of Oceanography, University of Washington, using a Technicon Model AAII and a Shimadzu TOC5000, respectively (Parsons et al. 1984).

Ozone chemistry: Total residual oxidant (TRO). TRO was determined using a standard DPD colorimetric analysis for total chlorine (APHA 1998). Hach Accu$\mathrm{Vac}^{\circledR}$ Ampules were submerged and filled with water immediately after this was collected from the ballast tank, and then analyzed on a Hach DREL/2010 water quality laboratory spectrometer on the ship. The ampoules had a range of 0 to $4.5 \mathrm{mg} \mathrm{l}^{-1}$ as $\mathrm{Br}_{2}$ with a sensitivity of $0.1 \mathrm{mg} \mathrm{l}^{-1}$ as $\mathrm{Br}_{2}$. TRO is a measure of halogen-containing oxidants. As described in the 'Introduction', ozone quickly reacts with bromide ion in seawater, forming hypobromous acid that is in equilibrium with hypobromite. Together, these compounds are referred to as bromines and they constitute TRO measured in the ozonation of seawater.

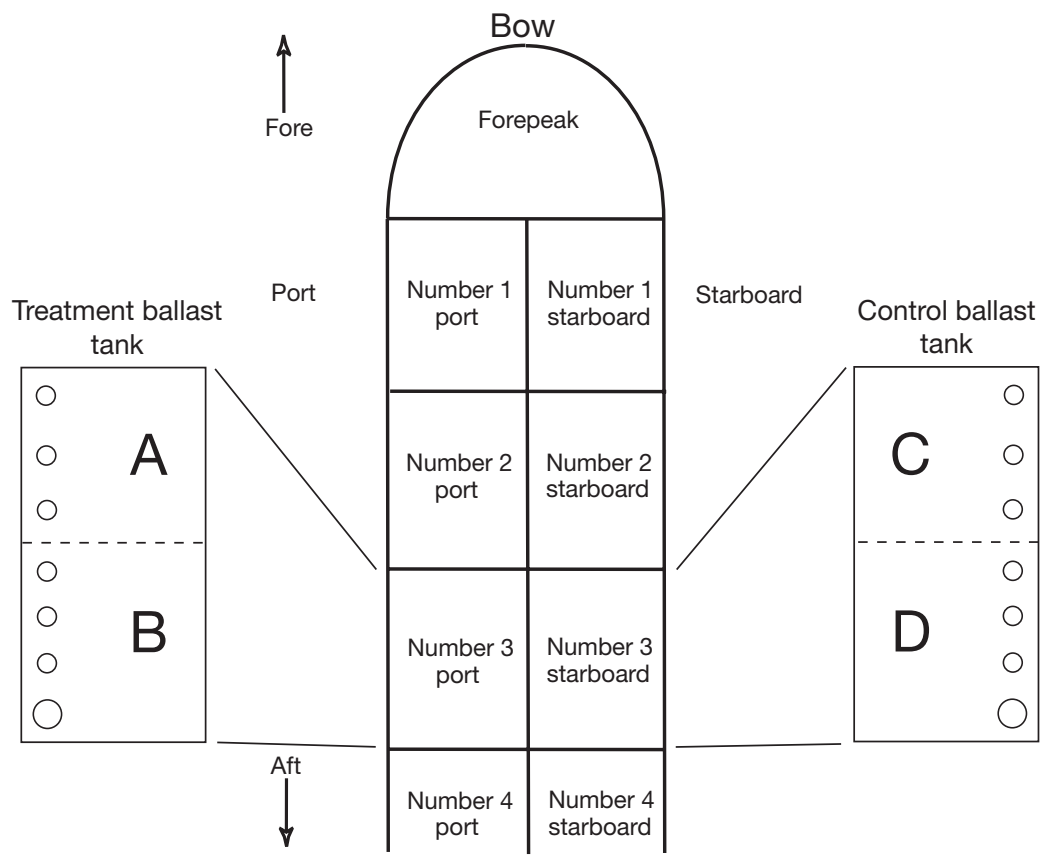

Fig. 2. Diagram of $S / T$ Tonsina showing locations of port and starboard ballast tanks. Samples were collected from fore and aft sections in treatment ballast tank (A and B) and control ballast tank (C and D). Circles: access hatches for treatment and control tanks; dashed lines: boundary between fore and aft sections. Figure is not to scale 
Ozone. Ozone was measured using the indigo colorimetric technique (APHA 1998). Similar to the TRO measurement, AccuVac ${ }^{\circledR}$ Ampules were used with freshly collected samples and analyzed using a Hach DREL/2010 water quality laboratory spectrometer. The ampoules had a range of 0 to $1.5 \mathrm{mg}^{-1}$, with a sensitivity of $0.1 \mathrm{mg} \mathrm{l}^{-1}$ ozone.

Oxidation reduction potential (ORP). ORP was measured using an Orion 290A pH meter with a ColePalmer Combination ORP probe (Pt electrode, Ag/ $\mathrm{AgCl}$ reference cell). ORP was measured in $\mathrm{mV}$.

Bromate. Samples for bromate ion analysis were collected in $150 \mathrm{ml}$ wide-mouth Nalgene HDPE bottles. They were stored on ice and shipped to analytical laboratories immediately after the end of each shipboard experiment. We used the US EPA Method 317.0 Revision 2.0 (EPA 815-B-01-001), which measures bromate ion from 2 to $40 \mu \mathrm{g} \mathrm{l^{-1 }}$.

For Expt 1, samples had a bromate concentration below the method detection limit of $2 \mu \mathrm{g} \mathrm{l^{-1 }}$. During the first set of analyses, we observed that control samples spiked with bromate were 'unrecoverable'. The subsequent evaluation of bromate standards prepared in distilled water showed good recovery. Experiments showed that at higher concentrations (i.e. at the $\mathrm{mg} \mathrm{l}^{-1}$ level), spiked bromate could be recovered. Subsequently, all ballast water samples were diluted to $20 \%$ of their original concentration (1 part ballast water: 4 parts distilled water) in distilled water. With this dilution, we determined that adequate bromate ion recovery could be achieved at the $50 \mathrm{ppb}$ level.

Based on bromate recovery following a 1:4 dilution, all ballast water samples for Expts 2 and 3 were diluted. This dilution enabled detection of $10 \mu \mathrm{g} \mathrm{l^{-1 }}$ bromate, which is the maximum contaminant level (MCL) established for bromate in drinking water (EPA 816-F-01-010).

Bromoform. Samples for bromoform analysis were collected in $40 \mathrm{ml}$ volatile organic analysis (VOA) vials containing a sulfite fixative. They were stored on ice and shipped to the analytical laboratory immediately after completion of each experiment. Bromoform was analyzed using a purge and trap gas chromatograph following US EPA Method 524.2 (EPA 600-R-95-131), using a Tekmar Model LSC-2000 liquid sample concentrator, interfaced with a Tekmar Model 2016 autosampler system, coupled to a Hewlett Packard 5890 Series II gas chromatograph. The chromatograph was equipped with a $30 \mathrm{~m}$ VOCOL capillary column, HP 3396A integrator/printer and flame ionization detector. Ultra pure carrier-grade helium gas was used for sparging samples. Bromoform standard was obtained from Ultra Scientific (North Kingstown, Rhode Island). The detection limit for bromoform was $5 \mathrm{~g} \mathrm{l} \mathrm{l}^{-1}$ and standards were prepared to $200 \mathrm{\mu g}^{-1}$.
Biology. Culturable heterotrophic bacteria: Viable heterotrophic bacteria were quantified using a culturebased microbiological procedure. For enumeration, a 11 sample from the Niskin sampler was placed in a sterile Nalgene plastic bottle and held on ice. Samples were transported on ice to the University of Washington laboratory and maintained on ice until processed. Samples were processed within $24 \mathrm{~h}$ of collection. Numbers of culturable heterotrophic bacteria were determined on marine R2A agar. This medium is a modification of R2A agar (Difco), which is commonly recommended for freshwater samples (APHA 1998). We prepared the marine R2A agar using ONR seawater salts. The formula for this marine salt solution at concentrations $\mathrm{l}^{-1}$ was: $\mathrm{NaCl}, 22.79 \mathrm{~g}_{;} \mathrm{Na}_{2} \mathrm{SO}_{4}, 3.98 \mathrm{~g}$; $\mathrm{KCl}, \quad 0.72$ g; $\mathrm{NaBr}, \quad 0.083$ g; $\mathrm{NaHCO}_{3}, 0.031$ g; $\mathrm{H}_{3} \mathrm{BO}_{3}, 0.027 \mathrm{~g}_{i} \mathrm{NaF}, 0.0026 \mathrm{~g}_{i} \mathrm{MgCl}_{2} \cdot 6 \mathrm{H}_{2} \mathrm{O}, 1.12 \mathrm{~g}$; $\mathrm{CaCl}_{2} \cdot 2 \mathrm{H}_{2} \mathrm{O}, 0.15 \mathrm{~g}_{i} \mathrm{SrCl}_{2} \cdot 6 \mathrm{H}_{2} \mathrm{O}, 0.0024 \mathrm{~g} ; \mathrm{FeCl} \cdot$ $4 \mathrm{H}_{2} \mathrm{O}, 0.0080 \mathrm{~g}$. The salts were prepared in 3 separate solutions: a $10 \times$ solution of 7 compounds $\left(\mathrm{NaCl}_{\text {, }}\right.$ $\mathrm{Na}_{2} \mathrm{SO}_{4}, \mathrm{KCl}, \mathrm{NaBr}, \mathrm{NaHCO}_{3}, \mathrm{H}_{3} \mathrm{BO}_{3}, \mathrm{NaF}$ ), a $50 \times$ solution of the divalent compounds $\left(\mathrm{MgCl}_{2}, \mathrm{CaCl}_{2}, \mathrm{SrCl}_{2}\right)$, and a $200 \times$ solution of $\mathrm{FeCl}$. The $10 \times$ solution was mixed with R2A agar, $\mathrm{pH}$ was adjusted to 7.6 , and the medium was sterilized by autoclaving at $121^{\circ} \mathrm{C}$. The medium was cooled in a water bath to $50^{\circ} \mathrm{C}$. Divalent cations solution $\left(20.0 \mathrm{ml} \mathrm{l}^{-1}\right.$ of a sterile $50 \times$ solution of $\mathrm{MgCl}_{2} \cdot 6 \mathrm{H}_{2} \mathrm{O}, \mathrm{CaCl}_{2} \cdot 2 \mathrm{H}_{2} \mathrm{O}, \mathrm{SrCl}_{2} \cdot 6 \mathrm{H}_{2} \mathrm{O}$ ) and $\mathrm{FeCl}_{2}$ solution $\left(5.0 \mathrm{ml} \mathrm{l}^{-1}\right.$ of a sterile $200 \times$ solution of $\mathrm{FeCl} \cdot 4 \mathrm{H}_{2} \mathrm{O}$ ) were added and mixed into the molten medium. The divalent cations and iron were added after autoclaving to minimize the formation of precipitate in the medium. Bacteria were enumerated using 2 methods. Aliquots of ballast water were inoculated onto the agar surface using the spread-plate method, or a larger volume of seawater was filtered through Pall Metricel ${ }^{\circledR}$ Black Membrane Disc Filters (47 mm diameter, $0.45 \mu \mathrm{m}$ pore size). Filters were placed on the surface of Marine R2A agar in a $50 \mathrm{~mm}$ diameter plastic petri plate. Filters were rolled onto the agar surface to prevent air bubbles from forming between the filter and agar surface. Larger $100 \mathrm{~mm}$ diameter petri dishes were used for the directly inoculated spread-plate method. Samples were inoculated in triplicate for each dilution, except for some filtered samples that were inoculated in duplicate. Inoculated media were incubated at room temperature (approximately $22^{\circ} \mathrm{C}$ ) in the dark. Bacterial colonies were counted on the spread-plate agar surfaces and membrane filters after $4 \mathrm{~d}$, when the colonies were large enough to see, but were not overlapping.

Phytoplankton and microflagellates: Subsamples (11) from the Niskin sampler were preserved on board ship in Lugol's iodine and shipped to the Smithsonian Environmental Research Center in Maryland for 
analyses. In each subsample, the number of cells present for each phytoplankton and microflagellate species (or lowest taxonomic unit) was counted directly under a compound microscope. First, 200 individual cells were counted for each of 20 fields at $500 \times$ magnification; this provided data for the number of cells for small species (e.g. microflagellates and dinoflagellates). Second, 20 fields were also examined at $312 \times$ magnification, to estimate the number of larger and less numerous forms.

To measure the effect of ozone treatment, changes in concentration (before and following 5 and $10 \mathrm{~h}$ of treatment) in the treatment and control tanks were compared. Counts were pooled across taxa for 3 major groups: dinoflagellates, microflagellates and diatoms. Species-level information was collected, but only effects on major taxonomic groups were compared, because there was high species composition variation both within replicates at a single collection time and among sampling periods. This higher taxa level approach was similar to the level of analysis for zooplankton and microbiology study components.

Mesozooplankton: A $0.3 \mathrm{~m}$ diameter, $73 \mu \mathrm{m}$ mesh zooplankton net was used for zooplankton collections. The net was lowered through hatches into Treatment Columns A and B and Control Columns C and D, to within $0.25 \mathrm{~m}$ of the tank bottom and slowly retrieved to the surface. We took 3 replicate vertical hauls from each hatch before ozone treatment, after $5 \mathrm{~h}$ (all experiments), and after $10 \mathrm{~h}$ (Expts 2 and 3). Samples were gently washed with filtered seawater from the net collecting bucket into a plastic specimen jar and kept cool by placing the jar on ice. Samples were immediately examined on the ship under a dissecting microscope. A field of view at $25 \times$ magnification was examined. Animal activity was scored as follows: animals moving or showing an escape response when probed with a fine needle (a 000 size insect pin mounted on a wooden stick), were scored as 'live'; those that were not mobile, but exhibited internal or external movement, were scored as 'moribund'; those with no internal or external movement were scored as 'dead'. Successive fields of view were examined until 100 organisms had been examined. In addition, qualitative observations were recorded about dominant taxa, and any taxa that appeared to be more or less affected by the treatment.

Toxicology. Caged animals: Caged organism experiments were designed to evaluate the effect of ozone treatment on a range of aquatic organisms, some that are typically used in aquatic toxicology experiments. The organisms included: mysid shrimp Americamysis bahia, sheepshead minnows Cyprinodon variegatus, purple shore crabs Hemigrapsus nudus and amphipods Rhepoxynius abronius. They were chosen based on their known sensitivity or hardiness to a variety of aquatic toxicants and their use as 'standard' laboratory test organisms. Mysid shrimp and sheepshead minnows were obtained from Aquatic Biosystems (Fort Collins, Colorado). Shore crabs and amphipods were collected from Puget Sound near Anacortes, Washington. All organisms were acclimated to Puget Sound seawater and maintained under either static or flowing seawater conditions at Western Washington University's Shannon Point Marine Laboratory, Anacortes, Washington. Prior to testing, organisms were placed in individual exposure chambers and transported to the $S / T$ Tonsina in ice chests containing aerated seawater. Animals and cages were not pre-selected for a treatment or control ballast tank. For the amphipods, 3 in situ chambers were put into a bucket containing sand at the bottom to act as an anchor, and were lowered to the bottom of the ballast tank $(15 \mathrm{~m})$. Each chamber contained 10 amphipods. Amphipod chambers were similar to those of Tucker \& Burton (1999), consisting of $5 \mathrm{~cm}$ diameter clear plastic tubes approximately $12 \mathrm{~cm}$ long enclosed at each end with polypropylene caps, with two $3 \times 5 \mathrm{~cm}$ ports made of $1 \mathrm{~mm}$ mesh. Chambers were soaked in both freshwater and seawater for $24 \mathrm{~h}$ to dissipate any construction-related toxicity. For mysid shrimp and sheepshead minnows, 10 individuals of each species were placed inside chambers (as described above) containing 2 rectangular windows $(3 \times$ $5 \mathrm{~cm}$ ) covered with $750 \mu \mathrm{m}$ mesh for mysid shrimp and $1 \mathrm{~mm}$ mesh for sheepshead minnows. For shore crabs, 10 individuals were placed into commercially available plastic crab bait buckets $(11 \mathrm{~cm}$ high $\times 9 \mathrm{~cm}$ diameter $)$ that were drilled with numerous $8 \mathrm{~mm}$ holes. Groups of 3 chambers, 1 for each species, were placed in coarsemesh polyethylene nets and attached to the tether rope with clamps, and deployed at specific depths in the ballast tank.

Groups of caged organisms were placed into the control and treatment tanks. Each exposure group consisted of a plastic bucket containing sand and connected to a tether rope. Buckets with amphipod exposure chambers were at the bottom of the ballast tank, with chambers for the other 3 species being suspended from the tether rope at approximately 1, 6 and $12 \mathrm{~m}$ ) from the ballast water surface. At the completion of the 5 or $10 \mathrm{~h}$ ozone treatment, cages were removed and the number of live, moribund or dead organisms was recorded. Amphipods were classified as moribund if they failed to rebury in the sand.

Whole effluent toxicity (WET) testing. Samples of ozone-treated water were collected at the end of each ozone treatment for laboratory toxicity testing of whole effluent toxicity (WET). We performed 2 standard acute toxicity tests: mysid shrimp Americamysis bahi $48 \mathrm{~h}$ static acute toxicity test, and topsmelt Atherinops 
affinis $48 \mathrm{~h}$ static acute toxicity test. These species are among the most sensitive to toxic chemicals in seawater (Suter \& Rosen 1988), and are commonly used to evaluate the toxicity of effluents discharged into marine waters. All toxicity tests were performed in accordance with standard regulatory procedures (US Environmental Protection Agency 1993, 1999). The seawater used as controls and for dilution of ballast water samples was prepared using laboratory water (1 $\mu \mathrm{m}$ filtered) and commercially available seawater salts (Hawaiian Marine Mix). The seawater salinity was $30 \pm 2$ PSU.

Mysid shrimp were obtained from Aquatic Biosystems (Fort Collins, Colorado). We exposed 5-d-old mysids for $48 \mathrm{~h}$ in a static test to 5 dilutions of ozonated ballast water: $6.25,12.5,25,50$ and $100 \%$, and to a dilution water control. A water temperature of $25 \pm 1^{\circ} \mathrm{C}$ and a 16:8 h light:dark cycle were maintained. Test solutions were not aerated and mysid shrimp were not fed during the tests. We used 4 replicate test solutions containing 5 to 10 shrimp per chamber at each treatment level in all tests. Procedures for the topsmelt tests were similar to those for the mysid shrimp. We exposed 15-d-old topsmelt larvae obtained from Aquatic Biosystems for $48 \mathrm{~h}$ in a static test to 5 dilutions of ozonated ballast water samples: 6.25, 12.5, 25, 50 and $100 \%$ ballast water and to a dilution water control.

\section{RESULTS}

\section{Chemistry}

Ozone delivery

Table 1 summarizes the water volume capacity of both sections of the ozone treatment tank (No. 3 port ballast tank) and number of ozone diffusers in each section, as well as the calculated ozone-loading rate in each section for each of the 3 experiments. Note that the 'Port, vertical portion' row in Table 1 gives infor- mation pertaining to the vertical wing tank, that is the portion from which samples for our experiments were taken. The ozone-loading rate in this wing tank increased by $22 \%$ between Expts 1 and 2, and then by $87.5 \%$ between Expts 2 and 3. This increase in ozone loading is generally reflected in the chemical and biological data presented below.

\section{Seawater chemistry}

The ballast water used in the experiments was collected by the $S / T$ Tonsina in northern Puget Sound and in the Straits of Juan de Fuca, near the Pacific Ocean. Observed salinities varied by less than 1 PSU in each experiment. Salinities were 33.3 to 33.7 PSU in Expt 1, 35.0 to 35.9 PSU in Expt 2, and 33.9 to 34.4 PSU in Expt 3. Salinity did not change in any tank during the experiments.

Water temperatures were slightly higher in Expt 1 than in the other 2 experiments. In Expt 1, water temperatures were 12.7 to $15.5^{\circ} \mathrm{C}$, while in the November experiments the temperatures were 9.4 to $11.8^{\circ} \mathrm{C}$. The temperature either remained the same or decreased slightly in all tanks.

The $\mathrm{pH}$ for all samples was typical of seawater, ranging from 7.4 to 7.9. In Expt 1, the $\mathrm{pH}$ was not as precisely measured as in the later experiments. There was no $\mathrm{pH}$ difference between the treatment and control tanks and it did not vary with time during the experiments.

DO in the ballast water was relatively high at the beginning of the experiments, at $\geq 8 \mathrm{mg} \mathrm{l}^{-1}$ in Expt 2 and $>6 \mathrm{mg} \mathrm{l}^{-1}$ in Expt 3. DO was not measured in Expt 1. DO generally increased during ozonation and maximum levels 2 to 3 times those of initial levels (approx. $20 \mathrm{mg} \mathrm{l}^{-1}$ ) were found at the end of the treatment. In the control tanks, the oxygen concentration did not increase during the experiment.

DOC measured at the beginning of each experiment was similar among all the experiments, and for the

Table 1. Estimated ozone production, distribution and loading in the total, horizontal and vertical portions of treatment tank in Expts 1, 2, and 3 performed onboard S/T Tonsina

\begin{tabular}{|c|c|c|c|c|c|c|c|c|c|c|c|c|}
\hline \multirow[t]{2}{*}{$\begin{array}{l}\text { Experimental } \\
\text { ballast tank } \\
\text { (No. 3) }\end{array}$} & \multirow[t]{2}{*}{$\begin{array}{l}\text { Volume } \\
\left(\mathrm{m}^{3} \times 10^{3}\right)\end{array}$} & \multirow[t]{2}{*}{$\begin{array}{l}\text { No. of } \\
\text { Diffusers }\end{array}$} & \multirow[t]{2}{*}{$\begin{array}{l}\text { Diffuser density } \\
\left(\mathrm{m}^{3} \text { diffuser }^{-1}\right)\end{array}$} & \multicolumn{3}{|c|}{$\begin{array}{c}\text { Ozone production } \\
\left(\mathrm{g} \mathrm{h}^{-1}\right)\end{array}$} & \multicolumn{3}{|c|}{$\begin{array}{c}\text { Ozone distribution } \\
(\%) \\
\text { Expt- }\end{array}$} & \multicolumn{3}{|c|}{$\begin{array}{l}\text { Ozone loading rate } \\
\left(\mathrm{mg} \mathrm{l}^{-1} \mathrm{~h}^{-1}\right) \\
\text { Expt }\end{array}$} \\
\hline & & & & 1 & 2 & 3 & 1 & 2 & 3 & 1 & 2 & 3 \\
\hline Port & 3.11 & 72 & $4.32 \times 10^{1}$ & 1460 & 1760 & 1660 & & & & 0.47 & 0.56 & 0.53 \\
\hline $\begin{array}{l}\text { Port, horizontal } \\
\text { portion }\end{array}$ & 1.88 & 56 & $3.36 \times 10^{1}$ & & & & 50 & 40 & 0 & 0.39 & 0.38 & 0.00 \\
\hline $\begin{array}{l}\text { Port, vertical } \\
\text { portion }\end{array}$ & 1.23 & 16 & $7.69 \times 10^{1}$ & & & & 50 & 60 & 100 & 0.59 & 0.72 & 1.35 \\
\hline
\end{tabular}


experimental and control samples collected within each experiment. DOC concentrations ranged from 0.7 to $1.1 \mathrm{mg} \mathrm{l}^{-1}$. Phosphate ranged from 0.06 to $0.07 \mathrm{mg} \mathrm{l}^{-1}$, silicate from 1.3 to $1.5 \mathrm{mg} \mathrm{l}^{-1}$, nitrate from 0.2 to $0.4 \mathrm{mg} \mathrm{l}^{-1}$, and nitrite from 0.004 to $0.006 \mathrm{mg} \mathrm{l}^{-1}$; ammonium ranged from $0.03 \mathrm{mg} \mathrm{l}^{-1}$ in Expt 1 to about twice that concentration $\left(0.07 \mathrm{mg} \mathrm{l}^{-1}\right)$ in Expts 2 and 3.

\section{Ozone chemistry}

In each experiment, TRO and ORP increased during the period of ozonation in the treatment tank (Table 2). TRO and ORP increases were not as great in Expt 1 with $5 \mathrm{~h}$ of ozonation, as in Expts 2 and 3 with $10 \mathrm{~h}$ of ozonation. Some of the concentrations exceeded the capacity for the colorimetric assay, i.e. were greater than $5 \mathrm{mg} \mathrm{l}^{-1}$ measured as $\mathrm{Br}_{2}$. In Expt 1, the highest TRO level found $\left(0.26 \mathrm{mg} \mathrm{l}^{-1}\right)$ was in the A15 location (Column A, $15 \mathrm{~m}$ from surface) at $5 \mathrm{~h}$. The highest TRO in Column B was approximately one-half this value. In Expts 2 and 3, the TRO levels exceeded $5 \mathrm{mg} \mathrm{l}^{-1}$ following 7.5 to $10 \mathrm{~h}$ of ozonation. The TRO levels increased more quickly in Column A than in Column B in the treatment tank. TRO levels were near $0.0 \mathrm{mg} \mathrm{l}^{-1}$ for all samples collected in the control ballast tank. The TRO achieved is a product of the ozone loading rate (Table 1) and the length of time that a column of seawater was treated. As described above, the ozone loading rate was highest in Expt 3 and lowest in Expt 1. Samples were not collected from Column D in the control ballast tank during Expts 2 and 3.

Seawater in the ballast tanks was well oxygenated at the start of the study and had very positive ORP values, measured as $\mathrm{mV}$. Following ozonation, the ORP values rapidly increased from approximately $100 \mathrm{mV}$ to over $600 \mathrm{mV}$. Maximum ORP values were between 780 and $799 \mathrm{mV}$. ORP values in the control tank fluctuated between 97 and $439 \mathrm{mV}$ with a mean of $260 \mathrm{mV}$.

Table 2. Total residual oxidant (TRO) and oxidation reduction potential (ORP) of treated and control ballast tanks in Expts 1, 2 and 3 performed onboard $S / T$ Tonsina. Location: letter represents column in ballast tanks, number represents distance (m) from ballast tank surface. Where 2 values are given, these are for duplicate analyses. $>5.00\left(\mathrm{TRO}>5.0 \mathrm{mg} \mathrm{Br}_{2} \mathrm{l}^{-1}\right)=\mathrm{out}_{\text {of }}$ range for assay, ns = not sampled

\begin{tabular}{|c|c|c|c|c|c|c|c|}
\hline \multirow[t]{2}{*}{ Location } & \multirow[t]{2}{*}{$\begin{array}{l}\text { Sample time } \\
\text { (h) }\end{array}$} & \multicolumn{3}{|c|}{ Total residual oxidant $\left(\mathrm{mg} \mathrm{Br}_{2} \mathrm{l}^{-1}\right)$} & \multicolumn{3}{|c|}{ Oxidation reduction potential $(\mathrm{mV})$} \\
\hline & & 1 & 2 & 3 & 1 & 2 & 3 \\
\hline \multirow[t]{5}{*}{ A3 } & 0.0 & $0.00,0.00$ & $0.06,0.07$ & $0.07,0.01$ & 129.5 & 77.1 & 71.6 \\
\hline & 2.5 & $0.21,0.43$ & $2.74,2.80$ & $4.02,4.07$ & 372.4 & 725.1 & 767.3 \\
\hline & 5.0 & $0.23,0.26$ & $2.39,2.37$ & $>5.00,>5.00$ & 718.9 & 774.3 & 761.6 \\
\hline & 7.5 & ns & $>5.00$ & $>5.00,>5.00$ & ns & 781.7 & 782.1 \\
\hline & 10.0 & ns & $>5.00,>5.00$ & $>5.00,>5.00$ & ns & 789.5 & 794.9 \\
\hline \multirow[t]{5}{*}{ A9 } & 0.0 & $0.00,0.00$ & $0.06,0.04$ & $0.02,0.02$ & 140.2 & 69.4 & 75.6 \\
\hline & 2.5 & $0.08,0.00$ & $2.70,2.78$ & $3.62,3.77$ & 363.7 & 738.3 & 750.7 \\
\hline & 5.0 & $0.20,0.03$ & $2.84,2.15$ & $>5.00,>5.00$ & 738.6 & 782.6 & 785.1 \\
\hline & 7.5 & ns & $>5.00,>5.00$ & $>5.00,>5.00$ & ns & 793.2 & 791.7 \\
\hline & 10.0 & ns & $>5.00,>5.00$ & $>5.00,>5.00$ & ns & 796.4 & 788.2 \\
\hline \multirow[t]{5}{*}{ A15 } & 0.0 & $0.00,0.00$ & $0.06,0.05$ & $0.00,0.01$ & 136.8 & 72.5 & 95.7 \\
\hline & 2.5 & $0.15,0.14$ & $0.37,0.39$ & $0.32,0.31$ & 289.7 & 629.3 & 574.8 \\
\hline & 5.0 & $0.24,0.26$ & $2.42,2.39$ & $2.68,2.72$ & 753.0 & 792.0 & 713.9 \\
\hline & 7.5 & ns & $4.70,4.62$ & $4.53,4.80$ & ns & 787.4 & 785.5 \\
\hline & 10.0 & $\mathrm{~ns}$ & $>5.00,>5.00$ & $>5.00,>5.00$ & $\mathrm{~ns}$ & 797.5 & 793.2 \\
\hline \multirow[t]{5}{*}{ B3 } & 0.0 & $0.00,0.01$ & $0.02,0.00$ & $0.00,0.00$ & 115.7 & 74.3 & 89.3 \\
\hline & 2.5 & $0.00,0.00$ & $0.57,0.56$ & $0.70,0.59$ & 217.0 & 297.1 & 637.5 \\
\hline & 5.0 & $0.10,0.01$ & $>5.00,>5.00$ & $2.90,3.80$ & 385.7 & 748.2 & 754.2 \\
\hline & 7.5 & ns & $3.89,3.94$ & $4.83,4.72$ & ns & 774.7 & 781.4 \\
\hline & 10.0 & ns & $>5.00,>5.00$ & $>5.00,>5.00$ & ns & 784.7 & 793.2 \\
\hline \multirow[t]{5}{*}{ B9 } & 0.0 & $0.05,0.02$ & $0.01,0.00$ & $0.00,0.01$ & 144.6 & 77.0 & 92.6 \\
\hline & 2.5 & $0.03,0.01$ & $0.85,0.84$ & $1.00,1.08$ & 217.3 & 981.0 & 721.1 \\
\hline & 5.0 & $0.02,0.00$ & $>5.00,>5.00$ & $3.98,3.96$ & 506.6 & 765.6 & 774.6 \\
\hline & 7.5 & ns & $4.40,4.37$ & $>5.00,>5.00$ & ns & 776.2 & 786.3 \\
\hline & 10.0 & ns & $>5.00,>5.00$ & $>5.00,>5.00$ & ns & 785.5 & 798.7 \\
\hline \multirow[t]{5}{*}{ B15 } & 0.0 & $0.01,0.03$ & $0.00,0.03$ & $0.00,0.00$ & 162.2 & 75.7 & 95.8 \\
\hline & 2.5 & $0.01,0.00$ & $0.63,0.61$ & $0.96,1.04$ & 339.9 & 672.3 & 716.9 \\
\hline & 5.0 & $0.09,0.17$ & $>5.00,>5.00$ & $4.14,4.12$ & 495.6 & 762.6 & 772.9 \\
\hline & 7.5 & ns & $3.91,3.96$ & $>5.00,>5.00$ & ns & 779.0 & 790.9 \\
\hline & 10.0 & ns & $>5.00,>5.00$ & $>5.00,>5.00$ & ns & 793.9 & 799.0 \\
\hline
\end{tabular}




\section{Disinfection byproduct chemistry}

We analysed 2 disinfection byproducts of possible concern, bromate and bromoform. Bromate was always below the method detection limit in all samples. When bromate was spiked into the treated samples in the laboratory, the spike was never recovered fully, indicating bromate demand in the water. The cause of this apparent demand was not understood; however, it may have been related to the high concentration of 'active' bromine (i.e. $\mathrm{HOBr} / \mathrm{OBr}^{-}$) in the samples.

In all 3 experiments, bromoform concentration increased over the ozonation period, with the maximum found at the last sampling (Table 3). Where a direct comparison was possible (i.e. from one experiment to another at the same time point), it was clear

Table 3. Bromoform data in ballast tank treated with ozone (Columns A and B of ballast tanks). All samples collected from control ballast tank (Columns $\mathrm{C}$ and D) were below method detection limit. Location: letter represents column in ballast tanks, number represents distance (m) from ballast tank surface. $<5.0$ (bromoform $<5.0 \mu \mathrm{g} \mathrm{l}^{-1}$ ) = below method detection limit, $\mathrm{ns}=$ not sampled

\begin{tabular}{|c|c|c|c|c|}
\hline \multirow[t]{2}{*}{ Location } & \multirow{2}{*}{$\begin{array}{l}\text { Sample } \\
\text { Time } \\
\text { (h) }\end{array}$} & \multicolumn{3}{|c|}{ Bromoform $\left(\mu \mathrm{g} \mathrm{l}^{-1}\right)$} \\
\hline & & 1 & 2 & 3 \\
\hline \multirow[t]{5}{*}{ A3 } & 0.0 & $<5.0$ & $<5.0$ & $<5.0$ \\
\hline & 2.5 & 35.0 & 62.0 & 74.6 \\
\hline & 5.0 & 136.0 & 77.4 & 77.7 \\
\hline & 7.5 & ns & 91.2 & 93.0 \\
\hline & 10.0 & $\mathrm{~ns}$ & 92.2 & 90.1 \\
\hline \multirow[t]{5}{*}{ A9 } & 0.0 & $<5.0$ & $<5.0$ & $<5.0$ \\
\hline & 2.5 & 30.0 & 68.4 & 80.0 \\
\hline & 5.0 & 145.0 & 76.0 & 90.3 \\
\hline & 7.5 & ns & 94.0 & 94.7 \\
\hline & 10.0 & ns & 98.0 & 105.6 \\
\hline \multirow[t]{5}{*}{ A15 } & 0.0 & $<5.0$ & $<5.0$ & $<5.0$ \\
\hline & 2.5 & 104.0 & 35.1 & 29.3 \\
\hline & 5.0 & ns & 75.2 & 75.2 \\
\hline & 7.5 & ns & 80.3 & 94.6 \\
\hline & 10.0 & ns & 82.4 & 96.1 \\
\hline \multirow[t]{5}{*}{ B3 } & 0.0 & $<5.0$ & $<5.0$ & $<5.0$ \\
\hline & 2.5 & $<5.0$ & 32.9 & 42.5 \\
\hline & 5.0 & 24.0 & 53.8 & 73.7 \\
\hline & 7.5 & ns & 73.6 & 96.5 \\
\hline & 10.0 & ns & 76.1 & 107.0 \\
\hline \multirow[t]{5}{*}{ B9 } & 0.0 & $<5.0$ & $<5.0$ & $<5.0$ \\
\hline & 2.5 & $<5.0$ & 44.6 & 55.5 \\
\hline & 5.0 & 47.2 & 70.4 & 70.6 \\
\hline & 7.5 & ns & 75.7 & 96.5 \\
\hline & 10.0 & $\mathrm{~ns}$ & 83.0 & 103.0 \\
\hline \multirow{5}{*}{ B15 } & 0.0 & $<5.0$ & $<5.0$ & $<5.0$ \\
\hline & 2.5 & $<5.0$ & 40.4 & 46.2 \\
\hline & 5.0 & 35.8 & 58.7 & 87.1 \\
\hline & 7.5 & ns & 74.8 & 79.0 \\
\hline & 10.0 & ns & 79.4 & 105.0 \\
\hline
\end{tabular}

that the concentration of bromoform increased more in Expt 1 than in either Expts 2 or 3, particularly in samples collected from Column A. In Expt 1, the maximum concentration of bromoform found was $145 \mathrm{\mu g} \mathrm{l}^{-1}$, in Expt 2 it was $98 \mu \mathrm{g} \mathrm{l}^{-1}$, and in Expt 3 it was $107 \mu \mathrm{g} \mathrm{l}^{-1}$. In Expt 3, the quantities of bromoform were very comparable between Columns A and B.

\section{Biology}

Culturable heterotrophic bacteria

The number of culturable bacteria was determined using either the direct spread-plate method or the membrane filtration method for each sample. The numbers presented (Table 4) were selected from the

Table 4. Enumerations of culturable heterotrophic bacteria from treated and control ballast tanks in Expts 1, 2, and 3 performed onboard $S / T$ Tonsina. Location: letter represents column in ballast tanks, number represents distance (m) from ballast tank surface. ${ }^{*}$ Sample enumerated in duplicate; other samples were enumerated in triplicate. $\mathrm{ns}=$ not sampled

\begin{tabular}{|c|c|c|c|c|}
\hline \multirow{2}{*}{ Location } & \multirow{2}{*}{$\begin{array}{c}\text { Time } \\
\text { (h) }\end{array}$} & \multicolumn{3}{|c|}{ Colony forming units (CFU) $\mathrm{l}^{-1}$} \\
\hline & & 1 & $\begin{array}{c}\operatorname{Expt} \\
2\end{array}$ & 3 \\
\hline A3 & $\begin{array}{c}0.0 \\
2.5 \\
5.0 \\
7.5 \\
10.0\end{array}$ & $\begin{array}{r}4.70 \times 10^{6} \\
1.00 \times 10^{4} \\
<3.00 \times 10^{3} \\
n \mathrm{~ns} \\
\mathrm{~ns}\end{array}$ & $\begin{array}{r}1.30 \times 10^{6} \\
1.00 \times 10^{1} \\
4.00 \times 10^{1} \\
<3.00 \times 10^{0} \\
<3.00 \times 10^{0}\end{array}$ & $\begin{array}{r}4.10 \times 10^{5} \\
1.00 \times 10^{1} \\
5.00 \times 10^{0 *} \\
5.00 \times 10^{0 *} \\
<5.00 \times 10^{0 *}\end{array}$ \\
\hline A9 & $\begin{array}{c}0.0 \\
2.5 \\
5.0 \\
7.5 \\
10.0\end{array}$ & $\begin{array}{l}2.70 \times 10^{6} \\
3.00 \times 10^{3} \\
<3.00 \times 10^{3} \\
n \mathrm{~ns} \\
\mathrm{~ns}\end{array}$ & $\begin{array}{r}9.20 \times 10^{5} \\
3.00 \times 10^{1} \\
3.00 \times 10^{0} \\
3.00 \times 10^{0} \\
<3.00 \times 10^{0}\end{array}$ & $\begin{array}{r}2.40 \times 10^{5} \\
7.00 \times 10^{0} \\
<5.00 \times 10^{0 *} \\
<5.00 \times 10^{0 *} \\
5.00 \times 10^{0 *}\end{array}$ \\
\hline A15 & $\begin{array}{c}0.0 \\
2.5 \\
5.0 \\
7.5 \\
10.0\end{array}$ & $\begin{array}{l}2.30 \times 10^{6} \\
<3.00 \times 10^{3} \\
<3.00 \times 10^{3} \\
n \mathrm{~ns} \\
\mathrm{~ns}\end{array}$ & $\begin{array}{r}9.30 \times 10^{5} \\
5.80 \times 10^{2} \\
<3.00 \times 10^{0} \\
1.00 \times 10^{1} \\
<3.00 \times 10^{0}\end{array}$ & $\begin{array}{r}3.20 \times 10^{5} \\
6.00 \times 10^{2} \\
2.00 \times 10^{1 *} \\
<5.00 \times 10^{0 *} \\
5.00 \times 10^{0 *}\end{array}$ \\
\hline B3 & $\begin{array}{c}0.0 \\
2.5 \\
5.0 \\
7.5 \\
10.0\end{array}$ & $\begin{array}{l}1.64 \times 10^{7} \\
1.09 \times 10^{6} \\
3.00 \times 10^{3} \\
\mathrm{~ns} \\
\mathrm{~ns}\end{array}$ & $\begin{array}{l}9.40 \times 10^{5} \\
9.00 \times 10^{2} \\
4.00 \times 10^{1} \\
1.00 \times 10^{1} \\
1.00 \times 10^{1}\end{array}$ & $\begin{array}{r}3.60 \times 10^{5} \\
1.20 \times 10^{3} \\
5.00 \times 10^{0 *} \\
<5.00 \times 10^{0 *} \\
<5.00 \times 10^{0 *}\end{array}$ \\
\hline B9 & $\begin{array}{c}0.0 \\
2.5 \\
5.0 \\
7.5 \\
10.0\end{array}$ & $\begin{array}{l}3.20 \times 10^{6} \\
6.40 \times 10^{5} \\
<3.00 \times 10^{3} \\
\text { ns } \\
\text { ns }\end{array}$ & $\begin{array}{r}8.70 \times 10^{5} \\
5.00 \times 10^{2} \\
3.00 \times 10^{1} \\
<3.00 \times 10^{0} \\
<3.00 \times 10^{0}\end{array}$ & $\begin{array}{r}3.20 \times 10^{5} \\
1.30 \times 10^{3} \\
7.00 \times 10^{0} \\
5.00 \times 10^{0 *} \\
<5.00 \times 10^{0 *}\end{array}$ \\
\hline B15 & $\begin{array}{c}0.0 \\
2.5 \\
5.0 \\
7.5 \\
10.0\end{array}$ & $\begin{array}{l}1.10 \times 10^{6} \\
2.40 \times 10^{5} \\
3.00 \times 10^{3} \\
\mathrm{~ns} \\
\mathrm{~ns}\end{array}$ & $\begin{array}{r}8.50 \times 10^{5} \\
3.00 \times 10^{2} \\
4.00 \times 10^{1} \\
1.00 \times 10^{1} \\
<3.00 \times 10^{0}\end{array}$ & $\begin{array}{r}5.20 \times 10^{5} \\
1.10 \times 10^{3} \\
7.00 \times 10^{0} \\
5.00 \times 10^{0 *} \\
<5.00 \times 10^{0} *\end{array}$ \\
\hline
\end{tabular}


Table 4 (continued)

\begin{tabular}{|c|c|c|c|c|}
\hline \multirow{2}{*}{ Location } & \multirow[b]{2}{*}{$\begin{array}{l}\text { Time } \\
\text { (h) }\end{array}$} & \multicolumn{3}{|c|}{ Colony forming units (CFU) $\mathrm{l}^{-1}$} \\
\hline & & 1 & $\begin{array}{c}\text { Expt } \\
2\end{array}$ & 3 \\
\hline \multicolumn{5}{|c|}{ C3 - control } \\
\hline & 0.0 & $2.30 \times 10^{6}$ & $1.10 \times 10^{6}$ & $7.00 \times 10^{5}$ \\
\hline & 2.5 & $1.10 \times 10^{6}$ & $3.70 \times 10^{7}$ & $6.40 \times 10^{5}$ \\
\hline & 5.0 & $6.00 \times 10^{5}$ & $8.40 \times 10^{5}$ & $7.20 \times 10^{5}$ \\
\hline & 7.5 & ns & $7.90 \times 10^{5}$ & $6.70 \times 10^{5}$ \\
\hline & 10.0 & ns & $7.60 \times 10^{5}$ & $6.20 \times 10^{5}$ \\
\hline \multicolumn{5}{|c|}{ C9- control } \\
\hline & 0.0 & $1.70 \times 10^{6}$ & $7.70 \times 10^{5}$ & $2.30 \times 10^{5}$ \\
\hline & 2.5 & $9.00 \times 10^{5}$ & $3.30 \times 10^{7}$ & $6.60 \times 10^{5}$ \\
\hline & 5.0 & $8.00 \times 10^{5}$ & $7.90 \times 10^{5}$ & $5.70 \times 10^{5}$ \\
\hline & 7.5 & ns & $7.70 \times 10^{5}$ & $6.00 \times 10^{5}$ \\
\hline & 10.0 & ns & $7.40 \times 10^{5}$ & $6.30 \times 10^{5}$ \\
\hline \multicolumn{5}{|c|}{ C15 - control } \\
\hline & 0.0 & $9.00 \times 10^{5}$ & $7.60 \times 10^{5}$ & $3.20 \times 10^{5}$ \\
\hline & 2.5 & $7.00 \times 10^{5}$ & $8.70 \times 10^{5}$ & $7.40 \times 10^{5}$ \\
\hline & 5.0 & $5.00 \times 10^{5}$ & $8.90 \times 10^{5}$ & $6.60 \times 10^{5}$ \\
\hline & 7.5 & ns & $7.80 \times 10^{5}$ & $6.70 \times 10^{5}$ \\
\hline & 10.0 & ns & $8.80 \times 10^{5}$ & $7.60 \times 10^{5}$ \\
\hline \multicolumn{5}{|c|}{ D3 - control } \\
\hline & 0.0 & $9.00 \times 10^{5}$ & ns & ns \\
\hline & 2.5 & $7.00 \times 10^{5}$ & ns & ns \\
\hline & 5.0 & $8.00 \times 10^{5}$ & ns & ns \\
\hline & 7.5 & ns & ns & ns \\
\hline & 10.0 & $\mathrm{~ns}$ & ns & ns \\
\hline \multicolumn{5}{|c|}{ D9 - control } \\
\hline & 0.0 & $8.00 \times 10^{5}$ & $\mathrm{~ns}$ & $\mathrm{~ns}$ \\
\hline & 2.5 & $5.00 \times 10^{5}$ & ns & ns \\
\hline & 5.0 & $6.00 \times 10^{5}$ & $\mathrm{~ns}$ & ns \\
\hline & 7.5 & ns & ns & ns \\
\hline & 10.0 & ns & $\mathrm{ns}$ & $\mathrm{ns}$ \\
\hline \multicolumn{5}{|c|}{ D15 - control } \\
\hline & 0.0 & $5.00 \times 10^{5}$ & ns & $\mathrm{ns}$ \\
\hline & 2.5 & $5.00 \times 10^{5}$ & $\mathrm{~ns}$ & $\mathrm{~ns}$ \\
\hline & 5.0 & $4.00 \times 10^{5}$ & ns & $\mathrm{ns}$ \\
\hline & 7.5 & ns & ns & $\mathrm{ns}$ \\
\hline & 10.0 & $\mathrm{~ns}$ & ns & $\mathrm{ns}$ \\
\hline
\end{tabular}

method that provided the best range of countable colonies for the sample. For example, for the ozonated seawater samples, the ozone treatment method was very effective in inactivating culturable heterotrophic bacteria. Therefore, if $100 \mu \mathrm{l}$ aliquots of treated seawater were inoculated onto the surface of marine R2A agar by the spread-plate method, typically no colonies would be found. Therefore, the culturable microorganisms were concentrated by using a membrane filtration method so that the sensitivity of the enumeration assay could be increased. The numbers in Table 4 are an average of the plating performed in triplicate or duplicate for each aliquot.

The number of culturable microorganisms was between $10^{5}$ and $10^{6} \mathrm{CFU}^{-1}$ before ozonation in treatment tanks and throughout the experiments in the control tanks (Table 4). A few samples had higher levels.
With ozonation, the number of viable bacteria had declined by the first $2.5 \mathrm{~h}$ sample. Except for the A15 sample collected in Expt 1, all of the $2.5 \mathrm{~h}$ samples collected from the treated tank in Expts 2 and 3 had lower numbers of culturable bacteria than those from Expt 1.

After $10 \mathrm{~h}$ of treatment (Expts 2 and 3), the bacteria population in the treated tank had decreased to $\leq 5.0 \mathrm{CFU} \mathrm{l}^{-1}$. One-third of the samples contained levels below the experimental detection limits (3.0 and 5.0 CFU $^{-1}$ for Expts 2 and 3, respectively). Samples collected at 7.5 and $10 \mathrm{~h}$ contained few if any viable bacterial cells. Therefore, ozonation using our methods reduced culturable microorganisms $>99.99 \%$.

One-third of the samples collected after $5.0 \mathrm{~h}$ of ozonation contained levels below the experimental detection limits (3.0 and 5.0 CFU ${ }^{-1}$ for Expts 2 and 3, respectively. Samples collected at 7.5 and $10 \mathrm{~h}$ contained few, if any, viable bacterial cells. Therefore, ozonation using our methods reduced the culturable microorganisms by $>99.99 \%$.

\section{Phytoplankton and microflagellates}

Since cells were preserved on board ship, our method could not be used to determine viability. Instead, dinoflagellate, diatom and microflagellate densities were estimated, assuming that decreases were due to cell death. During both Expts 2 and 3 when they were collected, dinoflagellate populations exhibited sharp decreases in both columns (A and B) in the ozone treatment tank relative to Column $\mathrm{C}$ in the control tank (Table 5). In Expt 2, samples collected $10 \mathrm{~h}$ after ozone treatment were reduced by 82 to $100 \%$ in Column A (with concentration increasing with increasing depth) and by $100 \%$ in Column B. For Expt 3, dinoflagellates were not detected after the $10 \mathrm{~h}$ treatment, resulting in a $>99 \%$ reduction. In contrast, dinoflagellates did not decline in any of the control tanks.

Initial concentration of microflagellates ranged from $2 \times 10^{5}$ to $3 \times 10^{5}$ cells $\mathrm{l}^{-1}$ in the treatment tank. Similar to dinoflagellates, microflagellates declined between 70 and $99 \%$ in Column A and between 93 and $98 \%$ in Column B during Expt 2. No spatial variation was evident in Expt 3, and microflagellates declined by 96 to $99 \%$. The initial concentration of microflagellates

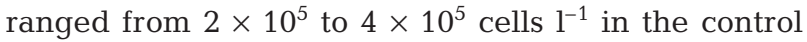
tank. In Expts 2 and 3, microflagellates did not decline in the control tank.

Diatom results were more variable. Concentrations varied from 17 to $135 \%$ of the initial concentrations in Expt 2 and from 20 to $120 \%$ of the initial concentrations in Expt 3 after $10 \mathrm{~h}$ ozonation. No decline was observed in the control tank. 
Table 5. Total numbers of dinoflagellates, diatoms, and microflagellates found in Expts 2 and 3. Samples were preserved onboard S/T Tonsina and later enumerated in laboratory. Location: letter represents column in ballast tank, number represents distance (m) from ballast tank surface. nd = no data

\begin{tabular}{|c|c|c|c|c|c|c|c|}
\hline \multirow{2}{*}{ Location } & \multirow{2}{*}{$\begin{array}{l}\text { Time } \\
\text { (h) }\end{array}$} & \multicolumn{3}{|c|}{$\longrightarrow$ Expt $2\left(\right.$ cells l $\left.^{-1}\right)-$} & \multicolumn{3}{|c|}{$\longrightarrow$ Expt $3\left(\right.$ cells l $\left.^{-1}\right)$} \\
\hline & & Dinoflagellates & Microflagellates & Diatoms & Dinoflagellates & Microflagellates & Diatoms \\
\hline \multirow[t]{3}{*}{$\mathrm{A} 3$} & 0.0 & $1.79 \times 10^{4}$ & $2.71 \times 10^{5}$ & $1.11 \times 10^{5}$ & $1.08 \times 10^{4}$ & $2.96 \times 10^{5}$ & $1.24 \times 10^{5}$ \\
\hline & 5.0 & $9.62 \times 10^{2}$ & $3.30 \times 10^{4}$ & $1.76 \times 10^{5}$ & 0 & $1.20 \times 10^{4}$ & $1.28 \times 10^{5}$ \\
\hline & 10.0 & 0 & $3.16 \times 10^{3}$ & $3.71 \times 10^{4}$ & 0 & $6.44 \times 10^{3}$ & $6.95 \times 10^{4}$ \\
\hline \multirow[t]{3}{*}{ A9 } & 0.0 & $5.92 \times 10^{3}$ & $2.70 \times 10^{5}$ & $8.34 \times 10^{4}$ & $1.20 \times 10^{4}$ & $2.57 \times 10^{5}$ & $6.74 \times 10^{4}$ \\
\hline & 5.0 & $1.02 \times 10^{3}$ & $1.65 \times 10^{4}$ & $5.66 \times 10^{4}$ & 0 & $4.76 \times 10^{3}$ & $6.77 \times 10^{4}$ \\
\hline & 10.0 & $8.80 \times 10^{2}$ & $8.10 \times 10^{4}$ & $1.13 \times 10^{5}$ & 0 & $9.06 \times 10^{3}$ & $1.25 \times 10^{5}$ \\
\hline \multirow[t]{3}{*}{ A15 } & 0.0 & $4.82 \times 10^{3}$ & $1.85 \times 10^{5}$ & $1.24 \times 10^{5}$ & $1.13 \times 10^{4}$ & $3.06 \times 10^{5}$ & $9.15 \times 10^{4}$ \\
\hline & 5.0 & $1.86 \times 10^{3}$ & $2.44 \times 10^{4}$ & $3.84 \times 10^{4}$ & $1.03 \times 10^{3}$ & $9.24 \times 10^{3}$ & $6.88 \times 10^{4}$ \\
\hline & 10.0 & $8.76 \times 10^{2}$ & $3.54 \times 10^{3}$ & $2.12 \times 10^{4}$ & 0 & $1.83 \times 10^{4}$ & $1.82 \times 10^{4}$ \\
\hline \multirow[t]{3}{*}{ B3 } & 0.0 & $1.27 \times 10^{4}$ & $2.84 \times 10^{5}$ & $1.52 \times 10^{5}$ & $1.10 \times 10^{4}$ & $2.63 \times 10^{5}$ & $5.34 \times 10^{4}$ \\
\hline & 5.0 & 0 & $1.06 \times 10^{4}$ & $5.82 \times 10^{4}$ & $1.20 \times 10^{3}$ & $1.58 \times 10^{4}$ & $1.01 \times 10^{5}$ \\
\hline & 10.0 & 0 & $1.97 \times 10^{4}$ & $2.94 \times 10^{4}$ & 0 & $5.89 \times 10^{3}$ & $6.84 \times 10^{4}$ \\
\hline \multirow[t]{3}{*}{ B9 } & 0.0 & $1.20 \times 10^{4}$ & $1.90 \times 10^{5}$ & $1.35 \times 10^{5}$ & $2.86 \times 10^{4}$ & $3.24 \times 10^{5}$ & $8.84 \times 10^{4}$ \\
\hline & 5.0 & 0 & $3.10 \times 10^{5}$ & $2.50 \times 10^{5}$ & $1.07 \times 10^{3}$ & $3.21 \times 10^{3}$ & $6.01 \times 10^{4}$ \\
\hline & 10.0 & nd & nd & nd & 0 & $8.86 \times 10^{3}$ & $5.86 \times 10^{4}$ \\
\hline \multirow[t]{3}{*}{ B15 } & 0.0 & $1.02 \times 10^{4}$ & $2.67 \times 10^{5}$ & $3.27 \times 10^{4}$ & $8.47 \times 10^{3}$ & $2.36 \times 10^{5}$ & $7.57 \times 10^{4}$ \\
\hline & 5.0 & 0 & $2.05 \times 10^{4}$ & $6.25 \times 10^{4}$ & $2.32 \times 10^{3}$ & $2.35 \times 10^{4}$ & $5.04 \times 10^{4}$ \\
\hline & 10.0 & 0 & $6.21 \times 10^{3}$ & $1.62 \times 10^{4}$ & 0 & $3.14 \times 10^{3}$ & $4.49 \times 10^{4}$ \\
\hline \multicolumn{8}{|c|}{ C3 - control } \\
\hline & 0.0 & $4.28 \times 10^{3}$ & $1.73 \times 10^{5}$ & $1.51 \times 10^{5}$ & $9.91 \times 10^{3}$ & $3.30 \times 10^{5}$ & $9.78 \times 10^{4}$ \\
\hline & 5.0 & $4.92 \times 10^{3}$ & $3.04 \times 10^{5}$ & $8.00 \times 10^{4}$ & $1.35 \times 10^{4}$ & $2.82 \times 10^{5}$ & $6.74 \times 10^{4}$ \\
\hline & 10.0 & $8.35 \times 10^{3}$ & $2.34 \times 10^{5}$ & $5.98 \times 10^{4}$ & $1.85 \times 10^{4}$ & $2.61 \times 10^{5}$ & $1.25 \times 10^{5}$ \\
\hline \multicolumn{8}{|c|}{ C9 - control } \\
\hline & 0.0 & $1.88 \times 10^{4}$ & $3.10 \times 10^{5}$ & $9.79 \times 10^{4}$ & $1.19 \times 10^{4}$ & $2.82 \times 10^{5}$ & $8.67 \times 10^{4}$ \\
\hline & 5.0 & $6.99 \times 10^{3}$ & $2.16 \times 10^{5}$ & $7.66 \times 10^{4}$ & $9.18 \times 10^{3}$ & $2.79 \times 10^{5}$ & $1.33 \times 10^{5}$ \\
\hline & 10.0 & $1.44 \times 10^{4}$ & $2.47 \times 10^{5}$ & $1.06 \times 10^{5}$ & $3.76 \times 10^{4}$ & $4.38 \times 10^{5}$ & $8.87 \times 10^{4}$ \\
\hline \multicolumn{8}{|c|}{ C15 - control } \\
\hline & 0.0 & $5.74 \times 10^{3}$ & $2.26 \times 10^{5}$ & $1.20 \times 10^{5}$ & $8.12 \times 10^{3}$ & $2.98 \times 10^{5}$ & $9.37 \times 10^{4}$ \\
\hline & 5.0 & $5.52 \times 10^{3}$ & $2.47 \times 10^{5}$ & $7.88 \times 10^{4}$ & $6.05 \times 10^{4}$ & $4.14 \times 10^{5}$ & $1.11 \times 10^{5}$ \\
\hline & 10.0 & $9.95 \times 10^{3}$ & $1.93 \times 10^{5}$ & $1.69 \times 10^{5}$ & $5.70 \times 10^{3}$ & $3.77 \times 10^{5}$ & $1.46 \times 10^{5}$ \\
\hline
\end{tabular}

\section{Mesozooplankton}

In the $5 \mathrm{~h}$ ozone exposure (Expt 1), the average percent of animals alive was uniformly high (range 94 to $97 \%$ ) in pre-treatment samples (Table 6). Mortality after $5 \mathrm{~h}$ was $91 \%$ in Column $\mathrm{A}$ and $47 \%$ in Column B.

The zooplankton assemblage in Expt 1 was dominated by the calanoid copepod Paracalanus sp., but also had several other relatively numerous copepods and larvae of barnacles, polychaetes and other animals. In qualitative observations, 2 taxa - the cyclopoid copepod Corycaeus anglicus and large Cirripedia (barnacle) nauplii-appeared relatively unaffected after $5 \mathrm{~h}$ ozone treatment. On the other hand, small calanoid copepod nauplii larvae were observed to have higher mortality than other mesozooplankton.

Similarly, in Expt 2, mortality at $5 \mathrm{~h}$ was different between the 2 treatments (A and B) (Table 6). In contrast to the Expt 1 conducted in September, survival was higher in Column A than in Column B. In addition,
$5 \mathrm{~h}$ mortality was lower than in Expt 1 (20\% in Column A, 66\% in Column B). After 10 h treatment, mortality increased, but the difference between the treatment columns persisted.

In Expt 3, mortality differences between the 2 treatment columns were much less and mortality was much higher at both sampling times (5 and $10 \mathrm{~h}$ ) than in the other experiments (Table 6 ); $>96 \%$ of the mesozooplankton were killed by $10 \mathrm{~h}$.

In Expts 2 and 3 conducted in November, diversity was much lower than in September (Expt 1). As in Expt 1, the zooplankton assemblage was dominated by the calanoid copepod Paracalanus sp. (mostly juveniles), but there were far fewer of the other taxa. Interestingly, in Expt 2 we observed a few Pseudodiaptomus marinus, an exotic Asian calanoid copepod, in most samples. As this species was not found in plankton tows from the ballast source water taken in Port Angeles harbor both day and night, it was assumed that they represented ballast water remnants from the ship's last voyage to Long Beach harbor, where P. marinus is established. 
Table 6. Effect of ozone treatment on mesozooplankton in Expts 1, 2 and $3(\mathrm{n}=3)$. Location: letter represents column in ballast tank

\begin{tabular}{|c|c|c|c|c|c|c|c|}
\hline \multirow{2}{*}{$\begin{array}{l}\text { Location } \\
\text { Expt } 1\end{array}$} & \multirow[t]{2}{*}{$\begin{array}{l}\text { Time } \\
\text { (h) }\end{array}$} & \multicolumn{2}{|c|}{$\begin{array}{r}\% \text { alive } \\
\text { avg. } \quad \text { SD }\end{array}$} & \multicolumn{2}{|c|}{$\begin{array}{l}\% \text { moribund } \\
\text { avg. SD }\end{array}$} & \multicolumn{2}{|c|}{$\begin{array}{l}\% \text { dead } \\
\text { avg. SD }\end{array}$} \\
\hline & & & & & & & \\
\hline A & 0.0 & 93.7 & 0.6 & 5.7 & 1.5 & 0.7 & 1.2 \\
\hline B & 0.0 & 95.3 & 1.2 & 3.7 & 2.1 & 1.0 & 1.0 \\
\hline C - control & 0.0 & 97.0 & 2.0 & 1.7 & 0.6 & 1.3 & 1.5 \\
\hline D - control & 0.0 & 95.7 & 1.5 & 3.0 & 1.0 & 0.3 & 0.6 \\
\hline A & 5.0 & 1.7 & 0.6 & 7.3 & 3.1 & 91.0 & 3.0 \\
\hline B & 5.0 & 25.0 & 4.0 & 27.7 & 0.6 & 47.3 & 3.5 \\
\hline $\mathrm{C}$ - control & 5.0 & 92.3 & 1.5 & 5.3 & 2.3 & 2.3 & 1.5 \\
\hline D - control & 5.0 & 92.7 & 2.9 & 6.0 & 2.6 & 1.3 & 0.6 \\
\hline \multicolumn{8}{|l|}{ Expt 2} \\
\hline A & 0.0 & 96.3 & 1.2 & 3.0 & 0.0 & 0.7 & 1.2 \\
\hline $\mathrm{B}$ & 0.0 & 93.7 & 1.5 & 4.0 & 1.7 & 0.3 & 0.6 \\
\hline C - control & 0.0 & 97.3 & 2.1 & 1.3 & 1.2 & 1.7 & 2.1 \\
\hline A & 5.0 & 40.3 & 3.2 & 39.7 & 8.5 & 20.0 & 6.2 \\
\hline B & 5.0 & 13.7 & 2.5 & 20.0 & 6.0 & 66.3 & 8.5 \\
\hline $\mathrm{C}$ - control & 5.0 & 97.7 & 1.5 & 2.3 & 1.5 & 0.0 & 0.0 \\
\hline A & 10.0 & 13.7 & 1.5 & 19.3 & 8.7 & 67.0 & 9.6 \\
\hline B & 10.0 & 1.7 & 1.2 & 1.0 & 1.0 & 97.3 & 2.1 \\
\hline $\mathrm{C}-\mathrm{control}$ & 10.0 & 94.3 & 3.8 & 5.0 & 3.6 & 0.7 & 0.6 \\
\hline \multicolumn{8}{|l|}{ Expt 3} \\
\hline A & 0.0 & 89.7 & 7.0 & 6.0 & 2.6 & 7.7 & 6.8 \\
\hline B & 0.0 & 94.7 & 2.5 & 2.3 & 1.5 & 3.0 & 1.0 \\
\hline $\mathrm{C}-$ control & 0.0 & 93.3 & 4.0 & 3.7 & 0.6 & 3.0 & 3.6 \\
\hline A & 5.0 & 7.7 & 5.7 & 8.3 & 4.2 & 84.0 & 7.0 \\
\hline B & 5.0 & 1.7 & 1.2 & 6.0 & 2.0 & 92.3 & 3.1 \\
\hline $\mathrm{C}-$ control & 5.0 & 97.0 & 1.0 & 1.0 & 1.0 & 3.3 & 1.2 \\
\hline A & 10.0 & 1.3 & 2.3 & 2.0 & 2.0 & 96.7 & 3.1 \\
\hline B & 10.0 & 0.0 & 0.0 & 0.7 & 1.2 & 99.3 & 1.2 \\
\hline C - control & 10.0 & 93.3 & 1.5 & 2.3 & 0.6 & 4.3 & 1.5 \\
\hline
\end{tabular}

This species, the harpacticoid copepod Microsetella sp. and nematode worms appeared to be more resistant to ozone treatment than the dominant Paracalanus sp., although overall mortality was very high.

\section{Toxicology}

\section{Caged animals}

Different mortalities were observed for different species of caged animals. For organisms suspended in the water column, sheepshead minnows usually had greatest mortalities, shore crabs least, and mysid shrimp intermediate mortalities. There were also differences between experiments and within a given treatment tank. In Expt 1, the organisms were exposed in 2 ozonated columns in 1 ballast tank and in 2 control columns in the control tank for $5 \mathrm{~h}$. Survival of control organisms was almost $100 \%$ (only 1 of 30 amphipods died, but 3 exposure chambers in Column $\mathrm{C}$ of the treatment tank were unfortunately lost) (Table 7); survival was also $100 \%$ for all species in Column B. In treatment Column $\mathrm{A}$, dead and moribund mysid shrimp ranged from 80 to $100 \%$; moribund and dead sheepshead minnows ranged from 80 to $100 \%$. Survival for both these species was directly related to depth: those closest to the bottom and nearest the ozone diffusers suffered highest mortality. In Column A, most of the mysid shrimp and sheepshead minnows died, except for mysid shrimp at the $1 \mathrm{~m}$ depth (Table 7).

In Expt 2, test organisms were exposed to a $10 \mathrm{~h}$ ozonation period in 3 treatment columns ( $\mathrm{A}, \mathrm{AB}-$ midway between $\mathrm{A}$ and $\mathrm{B}$ - and $\mathrm{B}$ ) and in 1 control column (D). Control survival was almost $100 \%$ for all species (1 of 30 mysid shrimp died), and none showed adverse effects (Table 7). For mysid shrimp in Column A of the treatment tank, percent dead varied (10 to $100 \%$ ). In contrast, $100 \%$ of the sheepshead minnows died and $100 \%$ of the shore crabs and amphipods lived. The pattern in the middle of the tank (Column AB) was somewhat similar, with $100 \%$ mortality for sheepshead minnows, 50 to $100 \%$ for mysid shrimp and $100 \%$ for shore crabs (except those nearest the ballast surface). In Expt 2, survival of all animals was greatest in Column B, with sheepshead minnows again having the greatest mortality. In Expt 2, all shore crabs survived and amphipods had only slight mortality (Table 7).

In Expt 3, all test organisms were exposed to ozone for $10 \mathrm{~h}$ in Columns $\mathrm{A}, \mathrm{AB}$, and $\mathrm{B}$ and to control conditions in 1 column (D). Control survival for this experiment was $100 \%$ and none of the control animals showed signs of stress (Table 7). Highest mortalities were observed in the treatment tank in Expt 3. Sheepshead minnows had 100\% mortality for all columns and depths; mysid shrimp, $100 \%$ for all samples collected in Column AB, $100 \%$ for 2 of the depths in Column A and 1 depth in Column B; shore crabs, $0 \%$ (but the shore crabs were moribund); amphipods, $7 \%$. All surviving shore crabs in the treatment tank were sluggish, and classified as moribund. In Expt 3, there was no obvious trend in survival rates with depth (although only mysid shrimp had partial kills, so data for this type of comparison was sparse). As in Expts 1 and 2, survival of mysid shrimp was highest in Column A, and amphipods had only slight mortality (Table 7).

\section{WET (acute toxicity) testing}

Tests conducted on mysid shrimp and topsmelt with control water samples (i.e. non-ozonated ballast water from the $S / T$ Tonsina) exhibited no or minimal toxicity (i.e. $<10 \%$ mortality) in all tests. For mysid shrimp, median lethal concentrations ranged from approxi- 
Table 7. Mysid shrimp Americamysis bahia, sheepshead minnows Cyprinodon variegatus, shore crabs Hemigrapsus nudus, and amphipods Rhepoxynius abronius. Percentage live and moribund in Expt 1 following 5 h ozonation and in Expts 2 and 3 following $10 \mathrm{~h}$ ozonation. Location: letter represents column in ballast tanks (A, B, AB, C, D) number represents distance (m) from ballast tank surface. Column AB was located between Columns A and B in treatment tank. nd = no data

\begin{tabular}{|c|c|c|c|c|c|c|c|c|c|c|c|c|}
\hline \multirow[t]{2}{*}{ Location } & \multicolumn{3}{|c|}{ Mysid shrimp } & \multicolumn{3}{|c|}{ Sheepshead minnows } & \multicolumn{3}{|c|}{ Shore crabs } & \multicolumn{3}{|c|}{$\begin{array}{c}\text { Amphipods } \\
\text { (avg. of } 3 \text { cages) }\end{array}$} \\
\hline & Live & Moribund & Dead & Live & Moribund & Dead & Live & Moribund & Dead & Live & Moribund & Dead \\
\hline \multicolumn{13}{|l|}{ Expt 1} \\
\hline A1 & 10 & 50 & 40 & 20 & 10 & 70 & 100 & 0 & 0 & & & \\
\hline A6 & 0 & 40 & 60 & 0 & 20 & 80 & 100 & 0 & 0 & & & \\
\hline A12 & 20 & 0 & 80 & 0 & 0 & 100 & 100 & 0 & 0 & & & \\
\hline A15 & & & & & & & & & & 100 & 0 & 0 \\
\hline B1 & 100 & 0 & 0 & 100 & 0 & 0 & 100 & 0 & 0 & & & \\
\hline B6 & 100 & 0 & 0 & 100 & 0 & 0 & 100 & 0 & 0 & & & \\
\hline B12 & 100 & 0 & 0 & 100 & 0 & 0 & 100 & 0 & 0 & & & \\
\hline B15 & & & & & & & & & & 100 & 0 & 0 \\
\hline C1 - control & 100 & 0 & 0 & 100 & 0 & 0 & 100 & 0 & 0 & & & \\
\hline C6 - control & 100 & 0 & 0 & 100 & 0 & 0 & 100 & 0 & 0 & & & \\
\hline C12 - control & 100 & 0 & 0 & 100 & 0 & 0 & 100 & 0 & 0 & & & \\
\hline C15 - control & & & & & & & & & & nd & nd & nd \\
\hline D1 - control & 100 & 0 & 0 & 100 & 0 & 0 & 100 & 0 & 0 & & & \\
\hline D6 - control & 100 & 0 & 0 & 100 & 0 & 0 & 100 & 0 & 0 & & & \\
\hline D12 - control & 100 & 0 & 0 & 100 & 0 & 0 & 100 & 0 & 0 & & & \\
\hline D15 - control & & & & & & & & & & 97 & 0 & 3 \\
\hline \multicolumn{13}{|l|}{ Expt 2} \\
\hline A1 & 0 & 0 & 100 & 0 & 0 & 100 & 100 & 0 & 0 & & & \\
\hline A6 & 27 & 0 & 73 & 0 & 0 & 100 & 100 & 0 & 0 & & & \\
\hline A12 & 90 & 0 & 10 & 0 & 0 & 100 & 100 & 0 & 0 & & & \\
\hline A15 & & & & & & & & & & 100 & 0 & 0 \\
\hline AB1 & 40 & 0 & 60 & 0 & 0 & 100 & 10 & 0 & 90 & & & \\
\hline AB6 & 0 & 0 & 100 & 0 & 0 & 100 & 100 & 0 & 0 & & & \\
\hline AB12 & 50 & 0 & 50 & 0 & 0 & 100 & 100 & 0 & 0 & & & \\
\hline AB15 & & & & & & & & & & 80 & 0 & 20 \\
\hline B1 & 56 & 22 & 22 & 0 & 30 & 70 & 100 & 0 & 0 & & & \\
\hline B6 & 63 & 25 & 12 & 0 & 0 & 100 & 100 & 0 & 0 & & & \\
\hline B12 & 80 & 10 & 10 & 20 & 60 & 20 & 100 & 0 & 0 & & & \\
\hline B15 & & & & & & & & & & 97 & 0 & 3 \\
\hline D1 - control & 100 & 0 & 0 & 100 & 0 & 0 & 100 & 0 & 0 & & & \\
\hline D6 - control & 100 & 0 & 0 & 100 & 0 & 0 & 100 & 0 & 0 & & & \\
\hline D12 - control & 90 & 0 & 10 & 100 & 0 & 0 & 100 & 0 & 0 & & & \\
\hline D15 - control & & & & & & & & & & 100 & 0 & 0 \\
\hline \multicolumn{13}{|l|}{ Expt 3} \\
\hline A1 & 100 & 0 & 0 & 0 & 0 & 100 & 0 & 100 & 0 & & & \\
\hline A6 & 0 & 0 & 100 & 0 & 0 & 100 & 0 & 100 & 0 & & & \\
\hline A12 & 0 & 0 & 100 & 0 & 0 & 100 & 0 & 100 & 0 & & & \\
\hline A15 & & & & & & & & & & 93 & 0 & 7 \\
\hline AB1 & 0 & 0 & 100 & 0 & 0 & 100 & 0 & 100 & 0 & & & \\
\hline AB6 & 0 & 0 & 100 & 0 & 0 & 100 & 0 & 100 & 0 & & & \\
\hline AB12 & 0 & 0 & 100 & 0 & 0 & 100 & 0 & 100 & 0 & & & \\
\hline AB15 & & & & & & & & & & 93 & 0 & 7 \\
\hline B1 & 0 & 0 & 100 & 0 & 0 & 100 & 0 & 100 & 0 & & & \\
\hline B6 & 0 & 80 & 20 & 0 & 0 & 100 & 0 & 100 & 0 & & & \\
\hline B12 & 100 & 0 & 0 & 0 & 0 & 100 & 0 & 100 & 0 & & & \\
\hline B15 & & & & & & & & & & 93 & 0 & 7 \\
\hline D1 - control & 100 & 0 & 0 & 100 & 0 & 0 & 100 & 0 & 0 & & & \\
\hline D6 - control & 100 & 0 & 0 & 100 & 0 & 0 & 100 & 0 & 0 & & & \\
\hline D12 - control & 100 & 0 & 0 & 100 & 0 & 0 & 100 & 0 & 0 & & & \\
\hline D15 - control & & & & & & & & & & 100 & 0 & 0 \\
\hline
\end{tabular}


Table 8. Mysid shrimp Americamysis bahia and topsmelt Atherinops affinis. Survival and median lethal concentration $\left(\mathrm{EC}_{50} / \mathrm{LC}_{50}\right.$ as \% ballast water) in acute toxicity WET (whole effluent treatment) tests with samples from Expts 1,2 and 3. Samples collected following ozonation

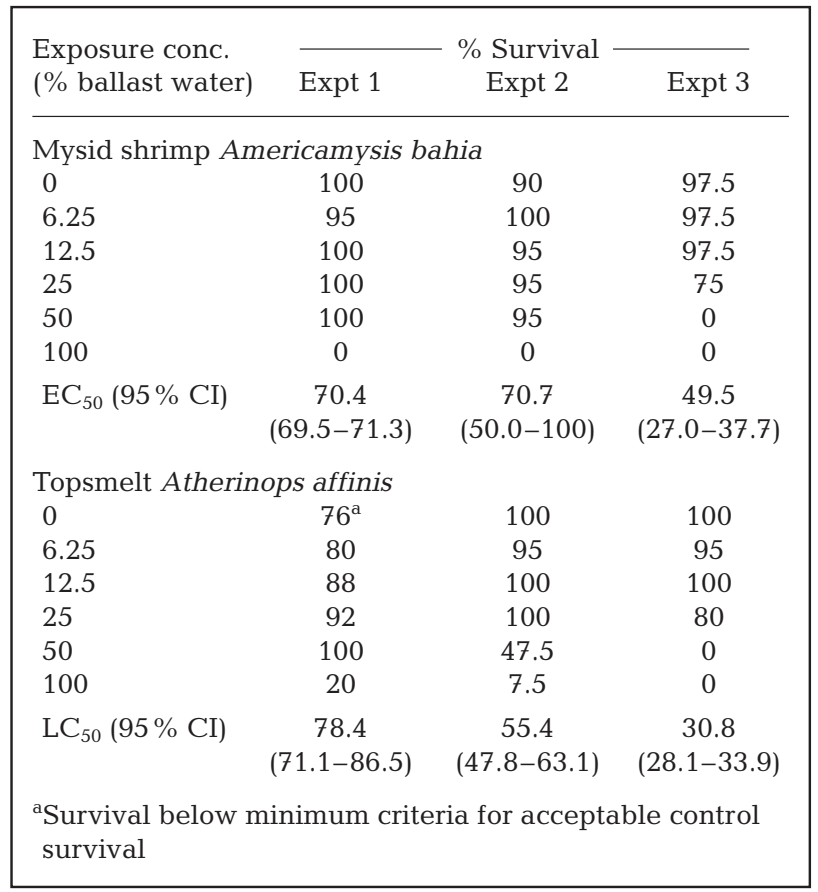

mately 50 to $70 \%$ in ozone-treated water. Topsmelt were slightly more sensitive, with median lethal concentrations ranging from approximately 30 to $80 \%$ in ozone-treated water (Table 8). Treated water from Expt 3 appeared more toxic (i.e. had lower median lethal concentrations) than in the other experiments.

\section{DISCUSSION}

The impact of ballast water treatments on the chemistry, biology and toxicity of the water must be understood before a potential treatment will be accepted by the shipping industry, regulatory agencies and other stakeholders. The expectations and regulatory environment for ballast water treatment are still being developed at the state, federal and international level. Results of only a few ballast water treatment systems on ships are documented in peer-reviewed literature. A few additional publications describe results of full-scale treatment systems that were evaluated at test bed facilities, but these are generally not as comprehensive as our shipboard study. Since we conducted our shipboard sampling in 2001, international and national treatment standards have been proposed and will probably influence future methods used in ballast water treatment experiments.

\section{Chemistry}

Water chemistry was homogeneous and similar between the treated and control tanks, and with depth in each water column before the ozone treatment began. Following ozonation, DO increased. This increase would probably not be detrimental to locations where ballast water is discharged, but it could accelerate corrosion of steel in ballast tanks where tank coating is deteriorated and steel is exposed. Deoxygenation is suggested as a method for reducing corrosion (Tamburri et al. 2002) and for eliminating organisms in ballast water (see later subsection).

Initially it was thought that the ozone itself would be the primary biocidal agent. However, it became apparent that bromine $\left(\mathrm{HOBr} / \mathrm{OBr}^{-}\right)$resulting from the rapid reaction of ozone with bromide ion was the effective oxidant. Bromine is known as an excellent biocide with residual properties, that is, it remains in solution for an extended time (Johnson \& Overby 1971, Crecelius 1979). This attribute is important for ballast water treatment that is performed in ballast tanks during a voyage because bromine can preclude the rebound of organisms with high reproductive potential.

It will be important to monitor the fate of biocides in ballast water treatments. In the case of ozonation, both ORP and TRO were considered. Results showed that TRO increased with increasing ozonation time, but ORP increased initially and then approached a maximum value that was nearly invariant with time of ozonation. These results coupled with the maintenance requirements of ORP electrodes due to tank intermittent dry/wet cycles, led to elimination of ORP as a monitoring tool. Measuring TRO is a simple and standard method, with well-developed field test procedures. Testing TRO is also fast, reliable, and relatively inexpensive. It is often used to control and monitor disinfection processes in wastewater treatment. Automated flow-through analyzers could be used for feedforward or feedback control of ozone dosage, and could be incorporated in the initial design of future ballast water treatment systems.

Our TRO chemistry and biological results indicated that the diffusers did not homogeneously distribute ozone throughout the ballast tank on the ship, either vertically or horizontally. Heterogeneity of the ozone distribution was a significant problem with the prototype treatment system. One reason is that ballast tanks within large ships have a significant amount of internal structure and platforms. These structures are designed to strengthen the hull of the ship and provide baffling so ballast water movement is minimized within the tank. When ballast water was treated by bubbling 
ozone from the diffusers, treated water did not easily circulate and mix within the treatment tank. Alternative methods of injecting ozone should be explored to provide a more homogeneous distribution of oxidant and biocide in ballast water tanks. In future research, some members of our research team will examine the efficacy of an ozone treatment system that injects ozone through a venturi installed in-line with the ballast pump pipe.

\section{Disinfection byproduct chemistry}

In this study, we examined the formation of 2 disinfection byproducts, bromate and bromoform (Fig. 1). Bromate was not detected in any samples. The presence of bromoform provided evidence that the oxidant residual was bromine, $\mathrm{HOBr} / \mathrm{OBr}^{-}$. Bromoform was formed in all 3 shipboard experiments, but was found in greatest concentration in Expt 1. Two major factors that may affect the creation of bromoform are DOC (part of NOM [natural organic matter] presented in Fig. 1) and temperature (Garcia-Villanova et al. 1997, Abd El-Shafy \& Grunwald 2000, Nikolaou \& Lekkas 2001). For all 3 experiments, the DOC was near $1 \mathrm{mg} \mathrm{l}^{-1}$ and differences were therefore probably not related to DOC concentrations. However, the temperature in Expt 1 was different than in Expts 2 and 3, and this may be the reason for the lower concentration of bromoform in the November experiments. When bromate was spiked into the treated samples in the laboratory, the spike was never recovered fully. The cause of this apparent demand is unknown, but may be related to the high concentration of 'active' bromine (i.e. $\mathrm{HOBr} / \mathrm{OBr}^{-}$) in the samples.

If TRO remains in seawater, it is likely that ozonated ballast water will continue to increase in bromoform concentration. A literature review suggests that the levels of bromoform found in our study will not adversely affect marine organisms. Toxicity data are available for phytoplankton Skeletonema costatum, Thalassiosira pseudonana, Glenodinium halli and Isochrysis galbana (Erickson \& Freeman 1978), mysid shrimp Americamysis bahia (US Environmental Protection Agency 1978), brown shrimp Penaeus aztecus (Andersen et al. 1979), Atlantic menhaden Brevoortia tyrannus (Andersen et al. 1979), and sheepshead minnow Cyprinodon variegates (Heitmuller et al. 1981, Ward 1981). Data for these species suggest that the quantity of bromoform produced during our shipboard experiments was not acutely toxic with $\mathrm{IC}_{50}$ (50\% inhibition concentration), $\mathrm{LC}_{50}$ (50\% lethal concentration), or NOEC (no observed effect concentration) values 1 to 2 orders of magnitude higher than the quantities we observed.

\section{Biology}

Mechanisms for removal and inactivation of organisms

Ozonation of seawater injures, kills, or lyses cells through the interaction of ozone or the residual oxidant (hypobromous acid and sodium hypobromite) with molecules within and on the surface of cells. For microorganisms, interaction with a significant level of an oxidant may cause the lysis of the cell. In other studies (data not shown), we observed a decrease in total numbers of microorganisms in seawater samples exposed to ozone that were stained with a nucleic acid stain and examined by epifluorescence microscopy or flow cytometry. Vissers et al. (1998) explained the mechanism of human red cell lysis by hypobromous acid by stating that it reacts with membrane lipids and proteins. Ozone has been used for many years to maintain water quality in seawater aquaculture settings. A low level of residual ozone is beneficial, but slightly higher levels $(>0.1$ $\mathrm{mg} \mathrm{l}^{-1}$ ) causes damage to gill membranes of fish. In general, fish may be more sensitive to residual ozone than invertebrates such as shrimp (Reid \& Arnold 1994).

\section{Culturable heterotrophic bacteria}

From our results, ozone was capable of eliminating $>99.99 \%$ of bacteria in ballast water. We attribute the toxicity of the treated seawater to the formation of bromines (measured in this study as TRO). If a significant amount of TRO remains in ballast water during a voyage, we conclude that heterotrophic microorganisms would continue to be inhibited. However, more recent laboratory studies have shown that when TRO disappears, marine heterotrophic microorganisms can rapidly rebound in number (Herwig et al. 2004).

Whether microorganisms, such as the heterotrophic bacteria enumerated in our study, should be regulated is somewhat controversial (Dobbs \& Rogerson 2005). For interim approval in the state of Washington, a treatment must reduce bacteria by $99 \%$ (Washington Department of Fish \& Wildlife 2002). The IMO (International Maritime Organization) Convention ignores most bacteria, other than those of public health significance including Vibrio cholerae strains O1 and O139, fecal coliforms, and fecal enterococci (IMO 2004). We did not attempt to enumerate bacteria of public health significance in our shipboard study.

\section{Phytoplankton and microflagellates}

Our results suggested that ozone had a strong effect on vegetative cells of dinoflagellates and microflagel- 
lates. The observed decline was probably due to lysis of vegetative cells caused by ozonation. Part of the observed decline could be from cells settling out, and we did not measure the accumulation of cells or resting stages at the bottom. However, because settling would also have occurred in the control ballast tank, mortality was still the most likely explanation for reduced densities of dinoflagellates and microflagellates in the treatment tank.

Although our results suggested that ozone may be much less effective for diatoms compared to dinoflagellates and microflagellates, this probably represented a limitation of microscopic methods used. Diatoms were identified based on the shape and patterns of their silica cell walls (frustules) that do not quickly degrade and disappear after ozonation. Thus, although counted in relatively high numbers following treatment, our method could not distinguish between live and dead individuals. We recommend that another method for quantifying and determining phytoplankton (and particularly diatom) viability be developed.

Overall, our results showed that ozone has promise for removing much of the phytoplankton from ballast water. In future tests, the measurement of chlorophyll a should be considered for assessing the impact of treatment on total phytoplankton biomass. This assay is relatively easy to perform using filtration and extraction with a solvent (Holm-Hansen \& Riemann 1978).

\section{Zooplankton}

Although mortality was variable and related to the ozone delivery efficiency, our results indicated that ozone treatment eliminated most zooplankton from ship's ballast. When ozone delivery was greatest in Expt 3, $>96 \%$ of the zooplankton was dead after $10 \mathrm{~h}$. Even in experiments where ozone delivery was less efficient, large proportions of the zooplankton were classified as moribund and these probably would not have survived. As with microorganisms, the presence of residual TRO would be expected to continue suppression of any remaining individuals.

The concentrations of all taxa were greatly decreased by ozone, but we qualitatively observed several that appeared more resistant to the treatment, including a known zooplankton invader, the calanoid copepod Pseudodiaptomus marinus. Laboratory mesoscale experiments with ozone using these taxa, including growing out treated water after dissipation of TRO, would be beneficial in further identifying resistant taxa and understanding how much ozone is required to eliminate them.

Unlike the samples collected at discrete depths in the ballast tank for microbiology and chemistry ana- lyses, zooplankton samples were an integration of organisms present in columns of ballast water. The observational method used to examine mesozooplankton was very intensive in that samples collected had to be quickly processed and observed onboard ship. The intensity of this analysis limited the total number of organisms that could be observed in order that all collected samples could be processed within a reasonable time. In addition, observations were limited by the mesh size of the plankton net. For our study, a $73 \mu \mathrm{m}$ mesh was used. The diagonal measurement for this mesh is about $100 \mu \mathrm{m}$, twice the length suggested by the IMO and pending legislation in the United States (see last subsection below). Based on our experience with this method, determinations of live, dead or moribund zooplankton and identification of taxa becomes more difficult when a smaller mesh is used.

\section{Toxicology}

Caged animals

Our caged experiments represent a novel approach for evaluating ship-scale ballast water treatment effects. Mortality of caged organisms exposed to ozone was variable, with the least mortality experienced by shore crabs and amphipods. The mechanism for mortality was likely to have been related to damage to gill tissues and the animals' respiratory system. As noted earlier, fish tend to be most sensitive to inactivation by oxidizing biocides (Reid \& Arnold 1994). Animals that are capable of minimizing their respiration or exchange with toxic water may avoid or delay the cellular damage caused by exposure to biocides.

Shore crabs and amphipods demonstrated the greatest resistance to ozone treatment. This outcome may be related to their natural history and physiology. Purple shore crabs Hemigrapsus nudus have a wide geographic range, being found on the west coast from Alaska to Mexico. This crab lives in the intertidal region in and out of water and is capable of withstanding a wide range of temperature, salinities and desiccation. $H$. nudus is an osmoregulatory organism and can tolerate both hypo- and hyper-osmotic conditions (Kozloff 1993, O'Clair \& O'Clair 1998). The amphipod Rhepoxynius abronius is a marine benthic organism that is widely used in sediment bioassays (Swartz et al. 1988, ASTM 1998). Interestingly, this amphipod demonstrated much greater resistance to ozone treatment than the other crustacean used in the shipboard tests, the mysid shrimp.

Mortality for the caged animals varied with location in the ballast tank, corroborating evidence from other measured parameters that ozone was not homoge- 
nously distributed in the tank. The ship's schedule only allowed for relatively short experiments, and caged organisms that did not show significant mortality after $10 \mathrm{~h}$ of exposure may have died after extended exposure to the treated water. Controlled toxicology laboratory experiments (see next subsection) would help answer questions about extended exposure to oxidizing biocides and delayed mortality, but our experience with the caged animal experiments suggest that this protocol should be considered in future shipboard experiments with biocide ballast water treatments.

\section{WET (acute toxicity) tests}

A limited number of WET tests were performed with water samples collected from ballast tanks of the $S / T$ Tonsina. For experiments conducted in Port Angeles, Washington, we were generally unable to have the WET samples delivered to the toxicology laboratory within $24 \mathrm{~h}$, so the amount of TRO present in the sampled water was reduced by the time of analysis. In a separate study (Jones et al. in press), the efficacy of ozone treatment was examined in the laboratory using adult mysid shrimp Americamysis bahia, juvenile topsmelt Atherinops affinis, sheepshead minnows Cyprinodon variegatus, and adults of 2 benthic amphipod species Leptocheirus plumulosus and Rhepoxinius abronius. Results from this well-controlled laboratory study showed a similar pattern of sensitivity to ozonetreated seawater as that seen in our shipboard caged animal experiments. Juvenile topsmelt and sheepshead minnows were the most sensitive to oxidant exposure, while the mysid shrimp was the most sensitive invertebrate. In contrast, benthic amphipods were the least sensitive of all species tested. Mortality from ozone exposure occurred quickly with median lethal times ranging from 1 to $3 \mathrm{~h}$ for the most sensitive species, although additional mortality was observed 1 to 2 $\mathrm{d}$ following ozone exposure (Jones et al. in press).

\section{Shipboard and full-scale testing of ballast water treatment systems}

Few published studies describe the results of fullscale treatment systems evaluated on ships or at test bed facilities. These include sequential hydrocyclonic and ultraviolet light systems (Sutherland et al. 2003, Waite et al. 2003), deoxygenation treatment (Tamburri et al. 2002), and heat (Rigby et al. 1999). The biological efficacy of the prototype ozone treatment system installed on the $S / T$ Tonsina generally compared well with previously described treatment technologies. Specific results are not directly comparable because the methods used for determining treatment efficacies were not similar. Some investigators took the strategy of adding a few representative organisms to ballast water and others examined only a few specific taxa that are present in seawater. In previous studies, bacterial populations were usually not enumerated. For our shipboard tests, we attempted to perform a more comprehensive examination of the organisms present in ballast water.

In recent experiments on deoxygenation, an inert gas generator was used to strip ballast water of oxygen and to introduce carbon dioxide and lower the $\mathrm{pH}$ (Tamburri et al. 2003). In the initial tests, 3 invasive invertebrates, Ficopomatus enigmaticus (serpulid polychaete), Carcinus maenas (European green shore crab) and Dreissena polymorpha (zebra mussel) were exposed to hypoxic conditions for 2 or $3 \mathrm{~d}$ in a ballast tank. Percent survival of all 3 species was reduced compared to controls, but the polychaete and zebra mussels demonstrated nearly $20 \%$ survival in the treated water. A comprehensive literature review (Tamburri et al. 2002) suggests that a variety of aquatic invertebrates and vertebrates can tolerate hypoxia or anoxia for a few days, and this treatment may therefore not be suitable for short voyages. Therefore, deoxygenation may not be suitable for coastal voyages such as on the west coast of the United States, where travel between ports may only be a few days. Rather than waiting a few days to observe the lethality of ozone treatment, all our experiments were performed within 5 to $10 \mathrm{~h}$, during which time the treatment rapidly killed a wide variety of organisms.

Waite et al. (2003) described large-scale experiments using commercially available units: a hydrocyclone, a self-cleaning $50 \mu \mathrm{m}$ screen, and an ultraviolet (UV) unit. In experiments conducted on Biscayne Bay (Florida) zooplankton, phytoplankton, microbiology, ATP and proteins were analyzed. Results showed that hydrocyclonic separation was ineffective and that the $50 \mu \mathrm{m}$ screen removed most of the zooplankton. UV treatment initially reduced the viable counts of microorganisms, but bacterial regrowth was observed in samples held for $18 \mathrm{~h}$. Unlike most biocides, UV treatment does not provide a residual toxicity in treated water. Waite et al. (2003) concluded that only the $50 \mu \mathrm{m}$ screen was effective in removing organisms, especially potential invaders such as larger zooplankton and invertebrate larvae. In our experiments, bacterial regrowth was not observed and zooplankton were largely eliminated, but as described earlier, a residual TRO must be maintained during a voyage to prevent the growth of bacteria.

Sutherland et al. (2001) evaluated a similar system, a cyclonic first stage followed by a UV phase, in British Columbia, Canada. Samples were collected from dif- 
ferent stages of the treatment. Invertebrates were assessed immediately after collection while phytoplankton were incubated for 'grow out'. Following treatment, dead and moribund copepods were observed, but low densities and high variances precluded statistical analyses of them. Phytoplankton analyses focused on 3 diatom species, Skeletonema costatum, Thalassiosira sp. and Chaetoceros gracile. Lowest concentrations and growth rates of these taxa were usually observed following UV treatment, with C. gracile being the most sensitive species. Our research team is interested in performing 'grow out' experiments for phytoplankton in future treatment tests, rather than enumerating phytoplankton in preserved samples. While the grow out method can determine viability of phytoplankton, the incubation period may last several weeks.

In an ocean trial, Rigby et al. (1999) conducted a shipboard experiment using heated water from the ship's main engine, flushed through a ballast tank, which resulted in complete elimination of zooplankton and limited survival of phytoplankton. The effect on bacteria was not reported. Small-scale laboratory work could be performed to determine the minimum temperatures and exposure times required to inactivate organisms found in ballast water.

\section{Ballast water treatment standards}

When we designed our sampling and analysis protocols for the shipboard experiments on the $S / T$ Tonsina, few regulatory agencies or governments had developed or promulgated standards for ballast water treatment. For example, the state of Washington treatment standards were released in 2001, and calls for 'inactivation or removal of ninety-five percent of zooplankton organisms and ninety-nine percent of phytoplankton and bacteria organism' (Washington Department of Fish \& Wildlife 2002). The United States has no standards for treatment, but legislation is pending before the US Congress. IMO (2004) adopted a convention that recommends member states adopt the following discharge standards for treated ballast water: 'Ships conducting ballast water management shall discharge less than 10 viable organisms per cubic metre greater than or equal to 50 micrometres in minimum dimension and less than 10 viable organisms per milliliter less than 50 micrometres in minimum dimension and greater than or equal to 10 micrometres in minimum dimension; and discharge of the indicator microbes shall not exceed the specified concentrations.' IMO standards were also suggested for selected bacteria of public health significance. The convention will come into force 12 mo after 30 countries, representing $35 \%$ of the world's shipping tonnage, ratify the convention. So far, only 1 country has ratified the convention and 7 others have stated that they intend to ratify it (Marine Environmental Protection Committee 2005). Obviously, scientists and engineers who are evaluating potential treatments must adapt their sampling and analysis methods to standards that are currently available or will be enforced in the future. The determination of viability for all the diversity of taxa present in seawater that includes microorganisms, phytoplankton and zooplankton is not a simple task. The proposed IMO standards require a high level of sensitivity and do not differentiate between taxonomic or functional groups. Numbers are for all organisms present in the selected size fractions.

We recommend that regulators, scientists and engineers engaged in ballast water research reach a consensus about suitable protocols for enumerating organisms and determining their viability; otherwise, the results from different research groups and technology vendors will be difficult to compare. Performing a comprehensive evaluation of the biology, chemistry and toxicology of a potential treatment system onboard a ship is a challenging task. A commercial vessel may not be the ideal platform for performing experiments with treatment systems, particularly if the voyage patterns and routes are not known well in advance. Commercial vessels do not have space dedicated for performing research or for sophisticated analytical and biological analyses. The primary effort of the ship's crew is to safely operate the vessel and transport cargo. Ship officers and crews are often very busy when their ship is in port and during a voyage, so it is difficult for them to lend a large amount of assistance to a science team. If ballast water treatment research is to be successfully conducted onboard commercial vessels, then regulatory agencies and governments must provide incentives to the shipping industry so this can participate and provide vessels for the development of ballast water treatment technology.

Acknowledgements. The cooperation of Alaska Tanker Corporation was essential to the successful completion of this project. We thank the Captain and the crew of the $S / T$ Tonsina for their cooperation in every aspect of performing the shipboard research. R. Mueller and staff from the Northeast Technical Services Company operated the Nutech-O3 ozone generator. G. M. Detloff provided help with the collection of samples for toxicology analysis. S. Sulkin, N. Schwarck, G. McKeen and A. Olah provided assistance with the caged animal studies. O. Kalata provided technical assistance in the identification of zooplankton from the $S / T$ Tonsina. BP Transportation (Alaska) and Nutech O3, provided partial funding for this project. Researchers from the University of Washington were supported in part from a US Fish and Wildlife research grant (98210-0-G738). The Regional Citizen's Advisory Council of Prince William Sound also provided support 
for G.M.R. and his staff from the Smithsonian Environmental Research Center. We thank the NOAA Sea Grant Program (NA16RG2251, NA16RG1681, NA16RG1044) and the US Fish and Wildlife Service (98210-0-G738) for research support during the latter stages of this study. Washington Sea Grant Program provided partial salary support to R.P.H.

\section{LITERATURE CITED}

Abd El-Shafy M, Grunwald A (2000) THM formation in water supply in south Bohemia, Czech Republic. Water Res 34: 3453-3459

Andersen DR, Bean RM, Gibson CI (1979) Biocide by-products in aquatic environments. Quarterly report covering period October 1 through December 31, 1978. Report No. US NTIS PNL-2941, Battelle Pacific Northwest Laboratory, Sequim, WA

APHA (American Public Health Association, American Water Works Association, Water Environmental Federation) (1998) Standard methods for the examination of water and wastewater, American Public Health Association, Washington, DC

ASTM (American Society for Testing and Materials) (1998) Standard guide for conducting 10-day static sediment toxicity tests with marine and estuarine amphipods. E136792, Vol 11.05. American Society for Testing and Materials, Philadelphia

Brunetto M, Colin C, Rosset R (1989) Solution chemistry and stability of bromamines - a high-performance reversed phase liquid-chromatography study. Analusis 17:112-118

Cloern JE (1996) Phytoplankton bloom dynamics in coastal ecosystems: a review with some general lessons from sustained investigation of San Francisco Bay, California. Rev Geophys 34:127-168

Cohen AN, Carlton JT, Fountain MC (1995) Introduction, dispersal and potential impacts of the green crab Carcinus maenas in San Francisco Bay, California. Mar Biol 122: 225-237

Crecelius EA (1979) Measurements of oxidants in ozonized sea water and some biological reactions. J Fish Res Board Can 36:1006-1008

Dobbs FC, Rogerson A (2005) Ridding ships' ballast water of microorganisms. Environ Sci Technol 39:259A-264A

Driedger A, Staub E, Pinkernell U, Marinas B, Koester W, von Gunten U (2001) Inactivation of Bacillus subtilis spores and formation of bromate during ozonation. Water Res 35: $2950-2960$

Erickson SJ, Freeman AE (1978) Toxicity screening of fifteen chlorinated and brominated compounds using four species of marine phytoplankton. In: Jolley RL, Gorchev H, Hamilton DH Jr (eds) Water chlorination: environmental impact and health issues. Ann Arbor Science, Ann Arbor, MI, p 307-310

Gallard H, von Gunten U, Kaiser HP (2003) Prediction of the disinfection and oxidation efficiency of full-scale ozone reactors. J Water Supply Res Technol Aqua 52: $277-290$

Garcia-Villanova RJ, Garcia C, Gomez JA, Garcia MP, Ardanuy R (1997) Formation, evolution and modeling of trihalomethanes in the drinking water of a town. 2. In the distribution system. Water Res 31:1405-1413

Grosholz ED, Ruiz GM, Dean CA, Shirley KA, Maron JL, Connors PG (2000) The impacts of a non-indigenous marine predator in a California bay. Ecology 81:1206-1224

Gujer W, von Gunten U (2003) A stochastic model of an ozonation reactor. Water Res 37:1667-1677
Haag WR, Hoigné J (1984) Kinetics and products of the reactions of ozone with various forms of chlorine and bromine in water. Ozone Sci Eng 6:103-114

Hallegraeff GM (1998) Transport of toxic dinoflagellates via ships' ballast water: bioeconomic risk assessment and efficacy of possible ballast water management strategies. Mar Ecol Prog Ser 168:297-309

Heitmuller PT, Hollister TA, Parrish PR (1981) Acute toxicity of 54 industrial chemicals to sheepshead minnows (Cyprinodon variegatus). Bull Environ Contam Toxicol 27: 596-604

Herwig RP, Cordell JR, Perrins JC, Ferm NC, Grocock JL, Blatchley ER III (2004) Mesocosm experiments for evaluating potential ballast water treatment systems. Fourth SETAC World Congress, Society for Environmental Toxicology and Chemistry (SETAC), Portland, OR

Hofman R, Andrews RC (2001) Ammoniacal bromamines: a review of their influence on bromate formation during ozonation. Water Res 35:599-604

Hoigné J (1998) Chemistry of aqueous ozone and transformation of pollutants by ozonation and advanced oxidation processes. In: Hubrec J (ed) The handbook of environmental chemistry quality and treatment of drinking water. Springer-Verlag, Berlin, p 83-141

Holm-Hansen O, Riemann B (1978) Chlorophyll a determination: improvements in methodology. Oikos 30:438-448

IMO (International Maritime Organization) (2004) International convention for the control and management of ships' ballast water and sediment. Available at: www.imo.org/Conventions/Mainframe.asp?topic_id=867

Johnson JD, Overby R (1971) Bromine and bromamine disinfection chemistry. J Sanit Eng Div ASCE 97:617-628

Jones AC, Gensemer RW, Stubblefield WA, Van Genderen E, Dethloff GM, Cooper WJ (in press) Toxicity of ozonated seawater to marine organisms. Environ Toxicol Chem

Kozloff E (1993) Seashore life of the northern Pacific coast. University of Washington Press, Seattle, WA

Langlais B, Reckhow DA, Brink DR (1991) Ozone in water treatment: application and engineering. Lewis Publishers, Chelsea, MI

Lei HX, Marinas BJ, Minear RA (2004) Bromamine decomposition kinetics in aqueous solutions. Environ Sci Technol 38:2111-2119

Marine Environmental Protection Committee (2005) Report of the Committee, paragraph 2.1. International Maritime Organization, London

Matheickal JT, Raaymakers S (2004) Second Intenational Ballast Water Treatment Symposium, 21-23 July 2003: Proceedings. GloBallast Monograph Series 15, International Maritime Organization (IMO), London

National Research Council (1996) Stemming the tide: controlling introductions of non-indigenous species. National Academy Press, Washington, DC

Nikolaou AD, Lekkas TD (2001) The role of natural organic matter during formation of chlorination by-products: a review. Acta Hydrochim Hydrobiol 29:63-77

O'Clair RM, O'Clair CE (1998) Southeast Alaska's rocky shores: animals. Plant Press, Auke Bay, AK

Oemcke D, van Leeuwen J (1998) Chemical and physical characteristics of ballast water: implications for treatment processes and sampling methods. Rep No. 23. CRC Reef Research Centre, Townsville, Queensland, Australia

Parsons TR, Maita Y, Lalli CM (1984) A manual of chemical and biological methods for seawater analysis. Pergamon Press, New York

Perrins JC, Cooper WJ, van Leeuwen H, Herwig RP (in press) Ozonation of seawater from different locations: formation 
and decay of total residual oxidant - implications for ballast water treatment. Mar Pollut Bull

Pimentel D, Lach L, Zuniga R, Morrison D (2000) Environmental and economic costs of non-indigenous species in the United States. Bioscience 50:53-65

Pinkernell U, von Gunten U (2001) Bromate minimization during ozonation: mechanistic considerations. Environ Sci Technol 35:2525-2531

Reid B, Arnold CR (1994) Use of ozone for water treatment in recirculating-water raceway systems. Prog Fish Cult 56: 47-50

Rigby GR, Hallegraeff GM, Sutton C (1999) Novel ballast water heating technique offers cost-effective treatment to reduce the risk of global transport of harmful marine organisms. Mar Ecol Prog Ser 191:289-293

Ruiz GM, Carlton JT, Grosholz ED, Hines AH (1997) Global invasions of marine and estuarine habitats by non-indigenous species: mechanisms, extent, and consequences. Am Zool 37:621-632

Ruiz GM, Fofonoff P, Hines AH (1999) Non-indigenous species as stressors in estuarine and marine communities: assessing invasion impacts and interactions. Limnol Oceanogr 44:950-972

Ruiz GM, Fofonoff P, Carlton JT, Wonham MJ, Hines AH (2000) Invasions of coastal marine communities in North America: apparent patterns, processes, and biases. Annu Rev Ecol Syst 31:481-531

Salhi E, von Gunten U (1999) Simultaneous determination of bromide, bromate and nitrite in low $\mu \mathrm{g} \mathrm{l}^{-1}$ levels by ion chromatography without sample pretreatment. Water Res 33:3239-3244

Suter GW II, Rosen AE (1988) Comparative toxicology for risk assessment of marine fishes and crustaceans. Environ Sci Technol 22:548-556

Sutherland TF, Levings CD, Elliott CC, Hesse WW (2001) Effect of a ballast water treatment system on survivorship of natural populations of marine plankton. Mar Ecol Prog Ser 210:139-148

Sutherland TF, Levings CD, Petersen S, Hesse WW (2003) Mortality of zooplankton and invertebrate larvae exposed to cyclonic pre-treatment and ultraviolet radiation. Mar Technol Soc J 37:3-12

Swartz RC, Kemp PF, Schults DW, Lamberson JO (1988) Effects of mixtures of sediment contaminants on the marine infaunal amphipod, Rhepoxynius abronius. Environ Toxicol Chem 7:1013-1020

Tamburri MN, Wasson K, Matsuda M (2002) Ballast water deoxygenation can prevent aquatic introductions while reducing ship corrosion. Biol Conserv 103:331-341

Tamburri MN, Little BJ, Ruiz GM, Lee JS, McNulty PD (2003) Evaluations of Venturi Oxygen Stripping ${ }^{\mathrm{TM}}$ as a ballast water treatment to prevent aquatic invasions and ship corrosion. In: Second International Ballast Water Treatment R\&D Symposium. International Maritime Organization, London, p 34-47

Tucker KA, Burton GA (1999) Assessment of nonpoint-source

Editorial responsibility: Otto Kinne (Editor-in-Chief),

Oldendorf/Luhe, Germany runoff in a stream using in situ and laboratory approaches. Environ Toxicol Chem 18:2797-2803

US Environmental Protection Agency (1978) In-depth studies on health and environmental impacts of selected water pollutants. Contract No. 68-01-4646, US Environmental Protection Agency, Duluth, MN

US Environmental Protection Agency (1993) Methods for measuring the acute toxicity of effluents and receiving waters to freshwater and marine organisms. US Environmental Protection Agency, Washington, DC

US Environmental Protection Agency (1999) Alternative disinfectants and oxidants guidance manual. Rep No. EPA 815-R-99-014, Office of Water, Washington, DC

Vissers MCM, Carr AC, Chapman ALP (1998) Comparison of human red cell lysis by hypochlorous and hypobromous acids: insights into the mechanism of lysis. Biochem J 330: 131-138

von Gunten U (2003a) Ozonation of drinking water: Part I. Oxidation kinetics and product formation. Water Res 37: 1443-1467

von Gunten U (2003b) Ozonation of drinking water: Part II. Disinfection and by-product formation in presence of bromide, iodide or chlorine. Water Res 37:1469-1487

von Gunten U, Oliveras Y (1998) Advanced oxidation of bromide-containing waters: bromate formation mechanisms. Environ Sci Technol 32:63-70

von Gunten U, Pinkernell U (2000) Ozonation of bromidecontaining drinking waters: a delicate balance between disinfection and bromate formation. Water Sci Technol 41: 53-59

von Gunten U, Bruchet A, Costentin E (1996) Bromate formation in advanced oxidation processes. J Am Water Works Assoc 88:53-65

Waite TD (2002) Rationale for ballast water treatment standards to minimize translocation of unwanted species. Mar Technol Soc J 36:29-37

Waite TD, Kazumi J, Lane PVZ, Farmer LL, Smith SG, Smith SL, Hitchcock G, Cap TR (2003) Removal of natural populations of marine plankton by a large-scale ballast water treatment system. Mar Ecol Prog Ser 258:51-63

Ward GS (1981) Early life stage toxicity tests with a salt water fish: effects of 8 chemicals on survival growth and development of sheepshead minnows (Cyprinodon variegatus). J Toxicol Environ Health 8:225-240

Washington Department of Fish \& Wildlife (2002) WAC 22077-095. Interim ballast water discharge standard approval process.

Wilcove DS, Rothstein D, Dubow J, Phillips A, Losos E (1998) Quantifying threats to imperiled species in the United States. Bioscience 48:607-610

Woodward JB, Parsons MG, Troesch AW (1992) Ship operational and safety aspects of ballast water exchange at sea. Mar Technol 31:315-326

Yang M, Uesugi K, Myoga H (1999) Ammonia removal in bubble column by ozonation in the presence of bromide. Water Res 33:1911-1917

Submitted: September 20, 2005; Accepted: February 13, 2006 Proofs received from author(s): September 26, 2006 